\title{
Sediment Provenance in the
} Baker-Martínez Fjord System (Chile, $48^{\circ}$ S) Indicated by Magnetic Susceptibility and Inorganic Geochemistry

\author{
Matthias Troch ${ }^{1 *}$, Sebastien Bertrand ${ }^{1}$, Benjamin Amann ${ }^{1}$, Dawei Liu', \\ Juan A. Placencia ${ }^{2}$ and Carina B. Lange ${ }^{3,4,5}$
}

\begin{abstract}
${ }^{1}$ Renard Centre of Marine Geology, Department of Geology, Ghent University, Ghent, Belgium, ${ }^{2}$ Departamento de Química Ambiental, Facultad de Ciencias, Universidad Católica de la Santísima Concepción, Concepción, Chile, ${ }^{3}$ Centro de Investigación Oceanográfica COPAS Sur-Austral and Departamento de Oceanografía, Universidad de Concepción, Concepción, Chile, ${ }^{4}$ Centro de Investigación Dinámica de Ecosistemas Marinos de Altas Latitudes (IDEAL). Universidad Austral de Chile, Valdivia, Chile, ${ }^{5}$ Scripps Institution of Oceanography, University of California, San Diego, La Jolla, United States
\end{abstract}

\section{OPEN ACCESS}

Edited by:

Selvaraj Kandasamy, Xiamen University, China

Reviewed by:

Yuan-Pin Chang,

National Sun Yat-sen University,

Taiwan

Madhavaraju Jayagopal, Universidad Nacional Autonoma de Mexico, Mexico

Prakash Babu Chakka, Council of Scientific and Industrial

Research (CSIR), India

*Correspondence: Matthias Troch matthias.troch@ugent.be

Specialty section:

This article was submitted to Marine Biogeochemistry,

a section of the journal Frontiers in Marine Science

Received: 20 January 2021 Accepted: 12 April 2021 Published: 13 May 2021

Citation:

Troch M, Bertrand S, Amann B, Liu D, Placencia JA and Lange $C B$ (2021) Sediment Provenance in the Baker-Martínez Fjord System (Chile, $48^{\circ} \mathrm{S}$ ) Indicated by Magnetic Susceptibility and Inorganic Geochemistry.

Front. Mar. Sci. 8:612309 doi: 10.3389/fmars.2021.612309
Fjord sediments are increasingly used as high-resolution archives of climate and environmental change, including variations in glacier mass balance and terrestrial hydrology. To accurately interpret such sediment records, it is crucial to comprehend sediment transport processes and determine sediment provenance. With this in mind, our main objective is to identify cost-effective parameters that can be used to reconstruct relative variations in the origin of sediments deposited in the BakerMartínez fjord system, which is located between the Northern (NPI) and Southern (SPI) Patagonian Icefields. We focus on estimating the proportions of sediment derived from each icefield, taking advantage of the clearly distinct lithologies that underlie NPI (Patagonian Batholith) and SPI (Eastern Andean Metamorphic Complex) glaciers. The magnetic susceptibility and inorganic geochemistry of 21 surface sediment samples collected along the fjord system and that of suspended sediment samples from the four main rivers that discharge at its heads were investigated. Results indicate that sediments derived from the NPI are characterized by higher magnetic susceptibility and $\log (\mathrm{Ti} / \mathrm{Al})$ values than those from the SPI, reflecting the mafic nature of the batholith. In fjords that receive contributions from both the NPI and SPI, magnetic susceptibility and $\log (\mathrm{Ti} / \mathrm{Al})$ primarily reflect sediment provenance. In fjords receiving sediment from only one icefield, however, these parameters are positively correlated with grain size and reflect the progressive settling of particles from the surficial plume. Our results suggest that magnetic susceptibility and log(Ti/Al) can be used to reconstruct sediment provenance within the Baker-Martínez fjord system, but that only log(Ti/Al) can provide quantitative estimates of the proportions of sediment derived from each icefield. Ultimately, applying these provenance indicators to long sediment cores from the BakerMartínez fjord system could allow reconstructing relative variations in sediment input from each icefield, which may in turn be interpreted as changes in river discharge and/or glacier mass balance.

Keywords: grain size, river suspended sediment, Patagonia, fjord sediment, Northern Patagonian Icefield, Southern Patagonian Icefield 


\section{INTRODUCTION}

Fjord sediments constitute valuable and high-resolution paleoenvironmental archives due to high accumulation rates of particles of glacial and fluvial origin (Syvitski and Shaw, 1995; Bianchi et al., 2020). Patagonian fjord sediments in particular are increasingly recognized as high-resolution archives of past climate and environmental changes (Lamy et al., 2010; Caniupán et al., 2014; Bertrand et al., 2017; Ríos et al., 2020). During the last decade, these archives have been extensively used to reconstruct changes in seismic activity (St-Onge et al., 2012; Van Daele et al., 2013; Piret et al., 2018; Wils et al., 2020), volcanic activity (Fontijn et al., 2014; Wils et al., 2018), precipitation (Lamy et al., 2010; Bertrand et al., 2014) and glacier variability (Bertrand et al., 2012a, 2017; Kilian and Lamy, 2012). However, accurately interpreting such sediment records requires a comprehensive understanding of terrestrial sediment transport processes and of the provenance of the sediments deposited in these fjords.

In fjords, terrestrial sediment transport is directly linked to river and/or glacier dynamics (Syvitski and Shaw, 1995; Bianchi et al., 2020; Hogan et al., 2020). When sediment-laden freshwater is discharged into a saline fjord, the freshwater mass forms a buoyant, hypopycnal plume that transports most of the finegrained suspended sediments seaward. On the contrary, the coarse bedload sediments settle relatively quickly near the river mouth or glacier front (Syvitski and Shaw, 1995). Settling of the suspended sediments from the hypopycnal plume occurs in response to a decreasing flow velocity and increasing salinity, which enhances flocculation, palletization and/or agglomeration (Syvitski and Shaw, 1995). Variations in this hydrodynamic system, due to e.g., seasonal variations in meltwater discharge, affect the flow velocity of the hypopycnal plume and its ability to transport suspended sediment, resulting in temporal changes in sediment grain size throughout the fjord system (Powell and Molnia, 1989; Cowan and Powell, 1990; Syvitski and Shaw, 1995; Bianchi et al., 2020).

Identifying sediment provenance is often an essential prerequisite for paleoclimate and paleoenvironmental reconstructions, since most fjords contain terrigenous sediments supplied by multiple sources. However, studies that evaluate the effectiveness of provenance tracers in Patagonian fjords are currently lacking. Recently, Liu et al. (2020) showed that bulk mineralogy and major and rare earth element geochemistry could be used to qualitatively reconstruct the provenance of Patagonian river sediments, whereas $\mathrm{Nd}$ and $\mathrm{Sr}$ isotopes allowed for quantitative provenance analysis. Likewise, Villaseñor et al. (2019) successfully used $\mathrm{Nd}$ and Sr isotopes to reconstruct Pleistocene glacial silt provenance to the continental slope at $46^{\circ} \mathrm{S}$. Measuring $\mathrm{Nd}$ and $\mathrm{Sr}$ isotopes is, however, timeconsuming and expensive, which limits its application on fjord sediment cores to a handful of pre-selected samples. A much more cost-effective provenance indicator that has shown promising results along the Chilean continental margin is bulk inorganic geochemistry. Some elemental ratios, such as $\mathrm{Fe} / \mathrm{Al}, \mathrm{Mg} / \mathrm{Zr}, \mathrm{Ti} / \mathrm{K}$, and $\mathrm{Ba} / \mathrm{Al}$ for instance, have proven to be reliable provenance indicators of sediments derived from different sources along the southern Andes (Klump et al.,
2000; Lamy et al., 2001; Stuut et al., 2007; Siani et al., 2010). Whether these indicators are also applicable to Patagonian fjord sediments has, however, not yet been evaluated. In proximal environments, some of these elements are known to be closely related to grain size (Bertrand et al., 2012b; Liu et al., 2019), which may limit their use as provenance tracers (Weltje, 2012).

With this in mind, the research objective of this paper is to identify cost-effective physical and geochemical parameters that can be used to reconstruct relative variations in the origin of sediments deposited in the Baker-Martínez fjord system (Chilean Patagonia, $48^{\circ} \mathrm{S}$ ). This fjord system is particularly promising to reconstruct past glacier variability, as it is located between the Northern (NPI) and Southern Patagonian Icefields (SPI). In addition, the distinct lithologies underlying both icefields, i.e., the Patagonian Batholith (NPI) and the Eastern Andean Metamorphic complex (SPI), suggest that compositional tracers could permit telling apart sediments derived from these two icefields. Previous studies highlighted the magnetic (Michelena and Kilian, 2015) and geochemical (Pankhurst et al., 1999; Faúndez et al., 2002; Augustsson and Bahlburg, 2003; Liu et al., 2020) differences that exist between the Patagonian Batholith and Eastern Andean Metamorphic Complex. Therefore, we focus on magnetic susceptibility and inorganic geochemistry, as these parameters are widely applicable and relatively easy to measure on both discrete samples (e.g., handheld magnetic sensors and ICP or XRF-based techniques) and on sediment cores (e.g., core logging and XRF core scanning). Both parameters are also relatively cheap to analyze and could thus complement lower-resolution isotope-based reconstructions (Revel-Rolland et al., 2005; Meyer et al., 2011; Bonneau et al., 2017).

\section{SETTING}

The $\sim 150 \mathrm{~km}$ long, W-E oriented Baker-Martínez fjord system is located between the NPI and the SPI, and it is subdivided into two parallel channels: Martínez in the north and Baker in the south (Figure 1). Both channels are interconnected near their heads via Troya Channel, and distally via Sierralta Channel. Each also has a series of tributary fjords, i.e., Steffen and Mitchell for Martínez, and Jorge Montt and Steele for Baker (Figure 1).

The Baker-Martínez fjord system has a hyperhumid maritime climate with a steep west-to-east precipitation gradient, due to the interaction of the southern westerlies with the Andes orographic high (Garreaud et al., 2013). Annual precipitation decreases from $>2,000 \mathrm{~mm} /$ year over the icefields to $<500 \mathrm{~mm} /$ year at the Chile-Argentina border (Figure 1; Fick and Hijmans, 2017). The mean air temperature of $c a$. $8^{\circ} \mathrm{C}$ remains relatively stable with longitude, but decreases with latitude (Sagredo and Lowell, 2012; Garreaud et al., 2013). Due to the cold climate and to the relatively recent deglaciation, physical weathering dominates and chemical weathering is relatively negligible (Kaiser et al., 2005; Bertrand et al., 2012b).

Freshwater enters the Baker-Martínez fjord system from four glacier-fed rivers, i.e., Baker, Pascua, Huemules and 

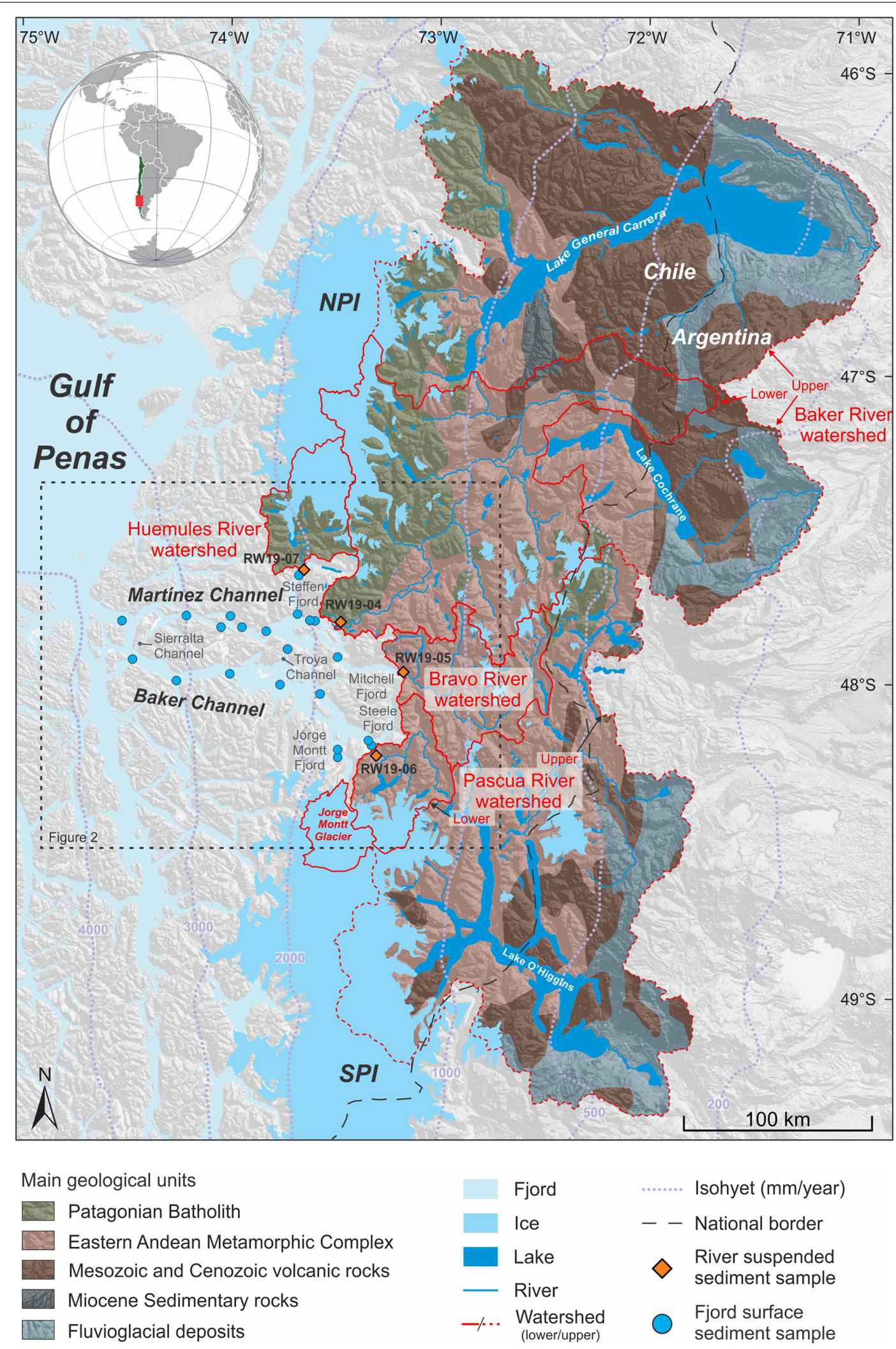

FIGURE 1 | Location of the Baker-Martínez fjord system in Chilean Patagonia with indication of the main geological units of the studied watersheds (Segemar, 2003; Sernageomin, 2003; Gómez et al., 2019), icefields (NPI and SPI; Northern and Southern Patagonian Icefield), mountain glaciers, and main rivers discharging in the fjord system. The mean annual precipitation (in $\mathrm{mm}$ ) gradient is represented by purple dashed isohyets (Fick and Hijmans, 2017). 
Bravo, and from Jorge Montt Glacier (Figure 1). Baker and Huemules rivers receive meltwater from NPI outlet glaciers, whereas Pascua River is mostly fed by the SPI. Bravo River is not connected to any icefield but it receives meltwater from isolated mountain glaciers. Baker, Pascua, and Bravo rivers have a nivo-glacial regime with glacial contributions during summer, whereas Huemules River is strictly proglacial (Aiken, 2012; González et al., 2013; Lara et al., 2015). Mean annual discharge varies by one order of magnitude across the four river watersheds: $1,133 \mathrm{~m}^{3} / \mathrm{s}$ (Baker), $753 \mathrm{~m}^{3} / \mathrm{s}$ (Pascua), $121 \mathrm{~m}^{3} / \mathrm{s}$ (Huemules), and $112 \mathrm{~m}^{3} / \mathrm{s}$ (Bravo) (Pantoja et al., 2011; Dussaillant et al., 2012; Pryer et al., 2020). Jorge Montt Glacier has an estimated mean annual discharge of ca. $129 \mathrm{~m}^{3} / \mathrm{s}$, based on a negative mass balance of $-2.20 \pm 0.38 \mathrm{Gt} /$ year (Foresta et al., 2018) and a mean annual precipitation of $3,752 \mathrm{~mm}$ (Boisier et al., 2018).
This estimate is in agreement with those from Mernild et al. (2017) (ca. $100 \mathrm{~m}^{3} / \mathrm{s}$ ) and Moffat et al. (2018) $\left(25-150 \mathrm{~m}^{3} / \mathrm{s}\right)$.

The hypopycnal plumes corresponding to the main freshwater sources flow in a westward direction through the Baker-Martínez fjord system toward the Gulf of Penas (Pérez-Santos et al., 2014; Ross et al., 2014). Consequently, the heads of Martínez and Baker channels receive meltwater and sediment from the NPI and SPI, respectively, before merging in the Troya Channel (Figure 2). Average spring-summer suspended sediment distributions quantified by MERIS-ENVISAT (2005-2011; González et al., 2013) and Landsat 8 (2016; International Initiative on Water Quality, 2019) satellite data reveal that NPI-derived meltwater and sediment can reach the distal part of Baker Channel through Troya and Sierralta channels (Figure 2). Water and sediments from the head of Baker

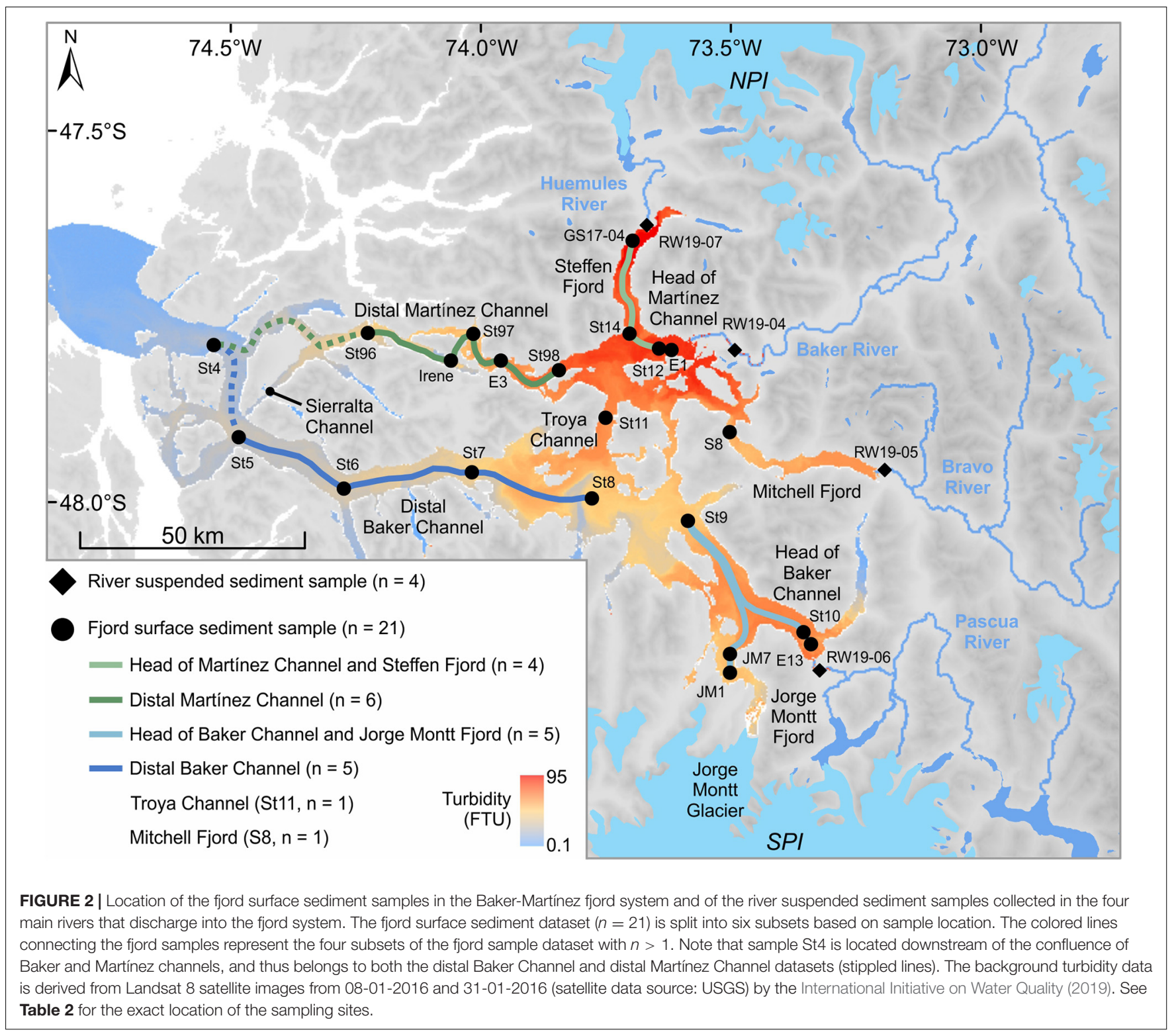


Channel, on the other hand, do not seem to cross over to the Martínez Channel.

Lithogenic particles constitute the majority (84.8-97.2 wt\%) of the sediments deposited in the Baker-Martínez fjord system. The rest is composed of organic matter (0.4-3.8 wt\%), biogenic opal (1.1-10.2 wt\%) and calcium carbonate (02.5 wt\%) (Rebolledo et al., 2019). Most of the lithogenic particles are derived from bedrock erosion by NPI and SPI glaciers, and are transported to the Baker-Martínez fjord system by the aforementioned glacier-river systems. Although some of the watersheds are $<10 \%$ glaciated, e.g., the Baker River watershed, the glacier-covered areas contribute significantly more water and sediments to the fjords than the drier regions (Figure 1; Dussaillant et al., 2012; Liu et al., 2020). In addition, suspended sediment data from the outflow of lakes General Carrera, Cochrane, and O'Higgins indicate that these lakes act as efficient sediment traps (HidroAysén, 2010; Vandekerkhove et al., 2020). Consequently, sediments from the upper Baker and upper Pascua river watersheds rarely reach the Baker-Martínez fjord system (Figure 1).

The regional geology mainly consists of two lithological units (Figure 1 and Table 1; Gómez et al., 2019): the Patagonian Batholith, which is mainly composed of granite, granodiorite, diorite, tonalite, and gabbro, under and around the NPI (Pankhurst et al., 1999; Hervé et al., 2007; Michelena and Kilian, 2015) and the Eastern Andean Metamorphic Complex, which is mainly composed of metamorphosed sandstone and mudstone, under and around the SPI (Faúndez et al., 2002; Augustsson and Bahlburg, 2003; Hervé et al., 2008). The relative proportions of these two lithologies vary considerably across the four watersheds (Table 1). The Eastern Andean Metamorphic Complex varies from $\sim 100 \%$ in the Bravo and lower Pascua river watersheds to $50 \%$ in the lower Baker River watershed, and the Patagonian Batholith varies from $100 \%$ in the Huemules River watershed to $36 \%$ in the lower Baker River watershed (Figure $\mathbf{1}$ and Table 1). Three additional lithologies occur in the easternmost reaches of our study region, i.e., Mesozoic and Cenozoic volcanic rocks, Miocene sedimentary rocks, and fluvioglacial deposits derived from Quaternary glacier advances (Kaplan et al., 2005; Boex et al., 2013; Davies et al., 2020).

\section{MATERIALS AND METHODS}

This study makes use of fjord surface sediment samples to evaluate the applicability of magnetic susceptibility and inorganic geochemistry as tracers of sediment provenance within the Baker-Martínez fjord system (Figure 1). Sediment grain size was also analyzed to estimate the influence of differential sediment settling from the hypopycnal plume on magnetic susceptibility and inorganic geochemistry (Snowball et al., 1999; Sandgren and Snowball, 2001; Bertrand et al., 2012b; Bloemsma et al., 2012; Lipp et al., 2020). In addition, suspended sediments from the four main rivers flowing into the Baker-Martínez fjord system were sampled at the
TABLE 1 | Surface area of the four studied river watersheds and Jorge Montt Glacier, and areal proportions of the corresponding bedrock lithologies (Gómez et al., 2019).

\begin{tabular}{lcccc}
\hline Watershed & Surface area (km²) & \multicolumn{3}{c}{ Bedrock lithology } \\
\cline { 3 - 5 } & & PB (\%) & EAMC (\%) & Other* (\%) \\
\hline Lower Baker River & 8,425 & 36 & 50 & 14 \\
Bravo River & 1,894 & 1 & 99 & 0 \\
Lower Pascua River & 1,125 & 0 & 100 & 0 \\
Huemules River & 1,102 & 100 & 0 & 0 \\
Jorge Montt Glacier & 500 & 0 & 100 & 0 \\
\hline
\end{tabular}

All parameters were calculated using ArcMap and the UTM18S projection. The Patagonian Batholith (PB) and Eastern Andean Metamorphic Complex (EAMC) are assumed to be the bedrock underlying the NPI and SPI, respectively (Figure 1; Gómez et al., 2019). *Other lithologies include Mesozoic and Cenozoic volcanic rocks, Miocene sedimentary rocks and fluvioglacial deposits (Figure 1; Segemar, 2003; Sernageomin, 2003; Gómez et al., 2019).

river mouths to characterize the physical and geochemical properties of the sediments reaching the fjord system (Figure 1). River sediments are preferred over bedrock samples since they integrate all the lithologies available within their respective watersheds.

\section{Sampling}

Twenty-one fjord surface sediment samples (Figure $\mathbf{1}$ and Table 2) were collected during five different campaigns carried out in the Baker-Martínez fjord system between 2013 and 2017: (1) CIMAR 20 Fiordos (November 2014), (2) COPAS Sur-Austral 2014 (October 2014; Rebolledo et al., 2019), (3) University of Washington field expedition to Jorge Montt Fjord (March 2013; Boldt, 2014), (4) PISCES 17 (February 2017), and (5) Ghent University field expedition to the Baker-Martínez fjord system (February 2017). These sediment samples were obtained using grab samplers or by sub-sampling the upper $1-2 \mathrm{~cm}$ of Rumhor, gravity, or Kasten cores.

River Water samples (RW19, Table 2) were collected in February 2019 (austral summer) at the mouths of the Baker, Pascua, Huemules and Bravo rivers (Figure 1). The upper $20 \mathrm{~cm}$ of the water column was sampled using a bucket from a boat. Between 100 and $155 \mathrm{~L}$ of water was collected per site, stored in pre-rinsed LDPE cubitainers $(10$ or $20 \mathrm{~L}$ ), and filtered using a $90 \mathrm{~mm}$ diameter PES membrane (pore size $0.22 \mu \mathrm{m}$ ) within 48 hours of collection. The volume (weight of water) of filtered water was recorded to calculate the suspended sediment concentration of each sample.

\section{Magnetic Susceptibility}

Volume-specific magnetic susceptibility was measured on all samples using a Bartington MS2G single-frequency $(1.3 \mathrm{kHz})$ sensor connected to a Bartington MS3 meter. Samples were packed into $1 \mathrm{~mL}$ plastic vials and the volume-specific values were divided by sample weight measured with a Mettler Toledo ME104T (0.1 mg) balance to calculate mass-specific 
TABLE 2 | Location of the fjord and river sediment sampling sites.

\begin{tabular}{|c|c|c|c|c|}
\hline Fjord/river & Station & Campaign* & Latitude & Longitude \\
\hline \multicolumn{5}{|c|}{ Fjord surface sediment samples } \\
\hline \multirow[t]{7}{*}{ Martínez Channel } & St96 & CF20 & -47.773 & -74.226 \\
\hline & Irene & $\mathrm{CO} 14$ & -47.811 & -74.063 \\
\hline & St97 & CF20 & -47.774 & -74.015 \\
\hline & E3 & $\mathrm{CO14}$ & -47.813 & -73.956 \\
\hline & St98 & CF20 & -47.823 & -73.844 \\
\hline & St12 & CF20 & -47.788 & -73.635 \\
\hline & E1 & $\mathrm{CO14}$ & -47.785 & -73.610 \\
\hline \multirow[t]{2}{*}{ Steffen Fjord } & St14 & CF20 & -47.768 & -73.694 \\
\hline & GS17-04 & UGent17 & -47.643 & -73.688 \\
\hline Troya Channel & St11 & CF20 & -47.881 & -73.742 \\
\hline \multirow[t]{8}{*}{ Baker Channel } & St4 & CF20 & -47.789 & -74.534 \\
\hline & St5 & CF20 & -47.913 & -74.484 \\
\hline & St6 & CF20 & -47.982 & -74.274 \\
\hline & St7 & CF20 & -47.960 & -74.018 \\
\hline & St8 & CF20 & -47.995 & -73.778 \\
\hline & St9 & CF20 & -48.025 & -73.586 \\
\hline & St10 & CF20 & -48.174 & -73.355 \\
\hline & E13 & $\mathrm{CO14}$ & -48.195 & -73.337 \\
\hline \multirow[t]{2}{*}{ Jorge Montt Fjord } & JM7 & UW13 & -48.203 & -73.502 \\
\hline & JM1 & UW13 & -48.228 & -73.502 \\
\hline Mitchell Fjord & S8 & $\mathrm{Pl} 17$ & -47.907 & -73.503 \\
\hline \multicolumn{5}{|c|}{ River suspended sediment samples } \\
\hline Baker River & RW19-04 & UGent19 & -47.796 & -73.492 \\
\hline Bravo River & RW19-05 & UGent19 & -47.957 & -73.193 \\
\hline Pascua River & RW19-06 & UGent19 & -48.225 & -73.323 \\
\hline Huemules River & RW19-07 & UGent19 & -47.628 & -73.668 \\
\hline
\end{tabular}

*CF20: CIMAR 20 Fiordos (November 2014).

CO14: COPAS Sur-Austral 2014 (October 2014, Rebolledo et al., 2019).

PI17: PISCES 17 (February 2017).

UGent17: Ghent University field expedition to the Baker-Martinez fjord system (February 2017).

UGent19: Ghent University field expedition (February 2019).

UW13: University of Washington field expedition to Jorge Montt Fjord (March 2013; Boldt, 2014).

magnetic susceptibility values (Sandgren and Snowball, 2001). All magnetic susceptibility measurements reported in this article are mass-specific.

\section{Inorganic Geochemistry}

Major (Al, $\mathrm{Ca}, \mathrm{Fe}, \mathrm{K}, \mathrm{Mg}, \mathrm{Mn}, \mathrm{Na}, \mathrm{P}, \mathrm{Si}$, and $\mathrm{Ti}$ ) and trace (Ba, $\mathrm{Sr}$, and $\mathrm{Zr}$ ) element concentrations were measured on the fjord surface and river suspended sediment samples by Inductively Coupled Plasma-Atomic Emission Spectrometry (ICP-AES). Here, we evaluate the ability of the lithogenic elements $\mathrm{Al}, \mathrm{Fe}$, $\mathrm{K}, \mathrm{Mn}, \mathrm{Ti}$, and $\mathrm{Zr}$ to reconstruct sediment provenance. The other elements were not considered as provenance indicators as their concentrations within fjord sediments are affected by variations in productivity (Ca, $\mathrm{Mg}, \mathrm{P}, \mathrm{Si}, \mathrm{Ba}$, and $\mathrm{Sr}$ ) or salinity $(\mathrm{Na})$ (Boyle, 2001; Raitzsch et al., 2010; Bertrand et al., 2012b; Faust et al., 2014; Liguori et al., 2016; Liu et al., 2020). All samples were prepared using the Li Metaborate fusion technique to ensure the complete dissolution of sediment, including refractory minerals such as zircon (Murray et al., 2000). ICP-AES analysis was performed at Ghent University (Varian 720-ES) and Université Libre de Bruxelles (Thermo Scientific iCAP ${ }^{\mathrm{TM}}$ 7000). Sample preparation consisted in mixing $200 \pm 0.5 \mathrm{mg}$ of Li-metaborate/Li-tetraborate (80:20 wt\%) or Li-metaborate/Li-bromide (98.50:1.50 wt\%) with $50 \pm 0.5 \mathrm{mg}$ of sediment in a Pt:Au crucible. To fuse the mixture, the crucible was placed in a muffle furnace for $12 \mathrm{~min}$ at $1,050^{\circ} \mathrm{C}$. The resulting glass bead was allowed to cool down for $2 \mathrm{~min}$. It was then transferred into a $50 \mathrm{~mL}$ beaker containing $25 \mathrm{~mL}$ of ultrapure $\mathrm{HNO}_{3}(5 \%)$. This solution was magnetically stirred for 60 to $90 \mathrm{~min}$ to dissolve the glass bead. Afterward, the solution was filtered $(0.45 \mu \mathrm{m}$ GHP membrane) and $5 \mathrm{~mL}$ was pipetted into a centrifuge tube containing $35 \mathrm{~mL}$ of ultrapure $\mathrm{HNO}_{3}(5 \%)$. The dilution factor $(\sim 4,000 \times)$ was calculated from the precise weight of sediment used for fusion. The inorganic geochemical data is presented as Supplementary Material (Supplementary Table 1).

Element concentrations were analyzed in terms of Al-based log-ratios (Weltje and Tjallingii, 2008; Bertrand et al., 2012b; Weltje, 2012). Al is useful as a normalizer since it occurs in comparable concentrations in most plutonic and metamorphic rocks (Calvert et al., 2001; McLennan et al., 2003), and is relatively independent of grain size and provenance (Bertrand et al., 2012b). This is confirmed for Patagonian bedrock and river sediments by Liu et al. $(2019,2020)$. The precision on all elemental ratios was better than $1 \%$, except for $\mathrm{K} / \mathrm{Al}$ (better than $2 \%$ ), and $\mathrm{Zr} / \mathrm{Al}$ (better than 4\%) (Bertrand et al., 2012b).

\section{Grain Size}

Grain size was determined on the terrigenous fraction of the sediment using a Malvern Mastersizer 3000 laser diffraction particle size analyzer. To isolate the terrigenous fraction, samples were treated with boiling $\mathrm{H}_{2} \mathrm{O}_{2}(2 \mathrm{~mL}, 30 \%), \mathrm{HCl}(1 \mathrm{~mL}, 10 \%)$ and $\mathrm{NaOH}(1 \mathrm{~mL}, 2 \mathrm{~N})$, to remove organic matter, carbonates and biogenic silica. The samples were then boiled with $\left(\mathrm{NaPO}_{3}\right)_{6}$ $(1 \mathrm{~mL}, 2 \%)$ to prevent flocculation and continuous ultrasounds (10\%) were used during analysis. A stirrer (2,500 rpm) kept the samples in suspension. The grain-size distributions were measured three times during $12 \mathrm{~s}$ per sample. The mode of the distributions was calculated using the Mastersizer 3000 v3.62 software. The grain size of sample RW19-05 (Bravo River) could not be analyzed due to a limited sample amount.

\section{Statistical Analysis}

Principal component analysis was carried out using XLSTAT 2016 after log-transforming the variables. Magnetic susceptibility and inorganic geochemistry were used as active variables, and the fjord surface sediment samples as active observations, to construct the principal component model. The grainsize mode was then projected as a supplementary variable, and the river suspended sediment samples as supplementary observations, in the principal component biplot.

To facilitate data interpretation, the fjord surface sediment dataset $(n=21)$ was split into six subsets based on sample location: (1) head of Martínez Channel and Steffen Fjord $(n=4)$, (2) head of Baker Channel and Jorge Montt Fjord $(n=5)$, (3) distal part of Martínez Channel $(n=6)$, (4) distal part of Baker Channel $(n=5)$, (5) 
Troya Channel $(n=1)$, and (6) Mitchell Fjord $(n=1)$ (Figure 2). Note that sample St4 is located downstream of the confluence of Baker and Martínez channels, and thus belongs to both the distal Baker Channel and distal Martínez Channel datasets.

\section{RESULTS}

\section{River Suspended Sediment Concentrations}

Suspended sediment concentrations measured in summer 2019 vary by a magnitude of $\sim 50$ over the four studied rivers. Huemules (57.2 $\mathrm{mg} / \mathrm{L}$ ) and Baker $(35.8 \mathrm{mg} / \mathrm{L})$ rivers have significantly higher suspended sediment concentrations than Pascua (5.2 $\mathrm{mg} / \mathrm{L})$ and Bravo (1.1 $\mathrm{mg} / \mathrm{L})$ rivers.

\section{Magnetic Susceptibility}

Magnetic susceptibility varies by a factor of $\sim$ seven between the four river suspended sediment samples (Figure 3). Suspended sediments from NPI-fed rivers, i.e., Huemules and Baker, have distinctly higher values (508 and $609.10^{-6} \mathrm{~m}^{3} / \mathrm{kg}$, respectively) than those from the SPI-fed Pascua River $\left(294.10^{-6} \mathrm{~m}^{3} / \mathrm{kg}\right)$. On the extreme end of the spectrum, suspended sediments from Bravo River have a magnetic susceptibility of 2,137 . $10^{-6} \mathrm{~m}^{3} / \mathrm{kg}$ (Figure 3).

A similar contrast in magnetic susceptibility is discernible between samples from the heads of the Baker-Martínez fjord system. Fjord surface sediment samples from the head of Martínez Channel and Steffen Fjord have relatively high values between 603 and $990 \cdot 10^{-6} \mathrm{~m}^{3} / \mathrm{kg}$, whereas samples from the head of Baker Channel and Jorge Montt Fjord have significantly lower values varying between 249 and $284 \cdot 10^{-6} \mathrm{~m}^{3} / \mathrm{kg}$

\section{Magnetic susceptibility $\left(10^{-6} \mathrm{~m}^{3} / \mathrm{kg}\right)$}

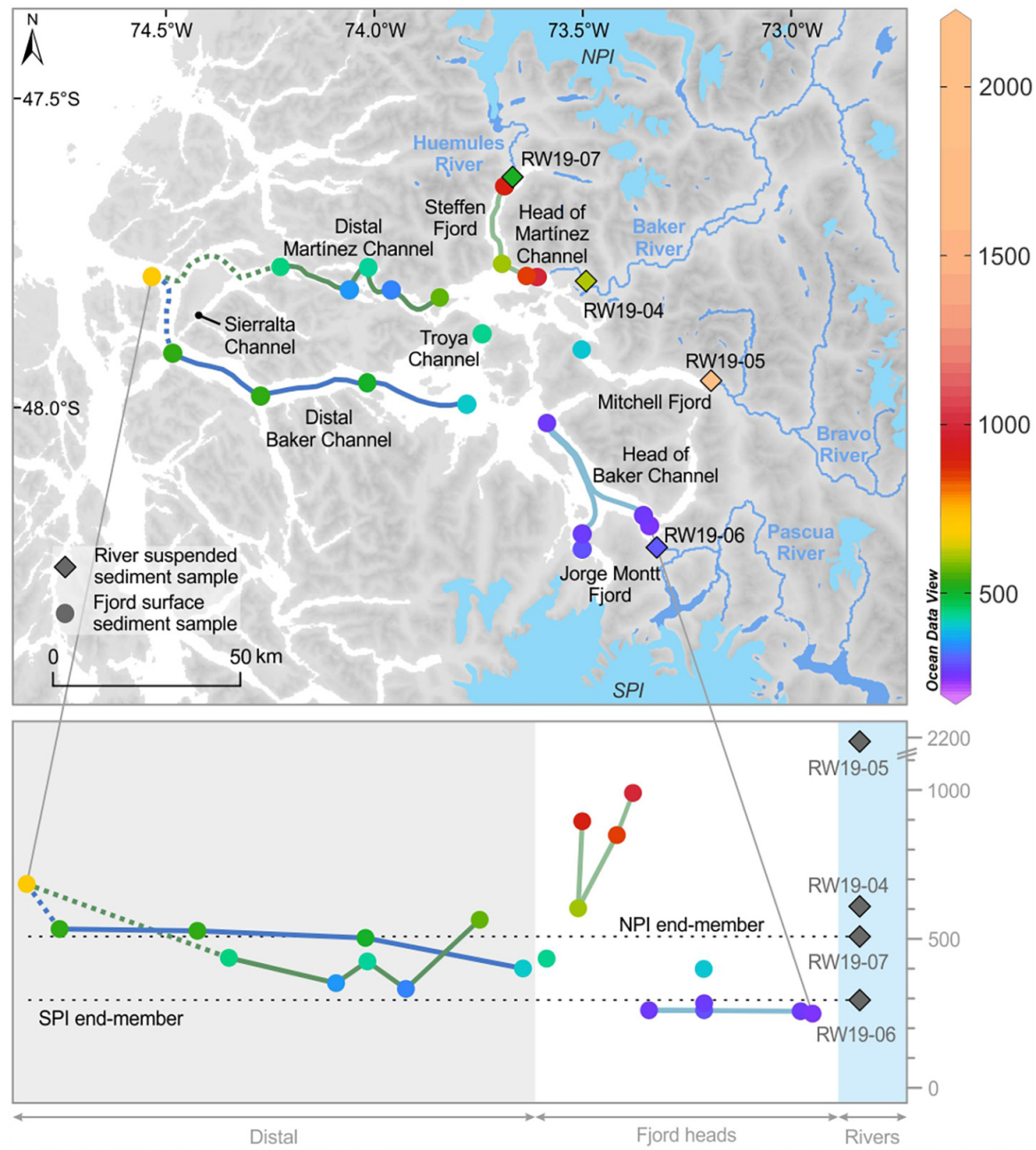

FIGURE 3 | Spatial variability in the magnetic susceptibility of the fjord and river sediment samples. The colored lines between the fjord samples represent the four subsets with $n>1$ (Figure 2). In the bottom panel, the fjord samples are plotted according to longitude. The provenance end-members are defined by the RW19-07 (NPI) and RW19-06 (SPI) river sediment samples. 
(Figure 3). In Mitchell Fjord, the surface sediment sample has a significantly lower magnetic susceptibility $\left(399 \cdot 10^{-6} \mathrm{~m}^{3} / \mathrm{kg}\right)$ compared to the suspended sediment sample from the river that flows into it (Bravo River; RW19-05; 2,137 . 10 $0^{-6} \mathrm{~m}^{3} / \mathrm{kg}$; Figure 3).

The relation between magnetic susceptibility and distance differs between channels (Figure 3). Whereas the magnetic susceptibility of the surface sediment samples is highly variable and does not have a clear trend with distance in Martínez Channel, it consistently increases westward in Baker Channel.

\section{Inorganic Geochemistry}

The principal component analysis of the fjord surface sediment samples (Figure 4) shows two principal components explaining $85 \%$ of the variance (PC1: 52\%, and PC2: 33\%). The first principal component mostly reflects the compositional difference between proximal (negative loadings) and distal (positive loadings) samples. The second principal component, on which magnetic susceptibility and $\log (\mathrm{Ti} / \mathrm{Al})$ have the highest loadings, mostly separates the Martínez Channel samples (top two quadrants), from those from Baker Channel (bottom quadrants).

The river suspended sediment sample from Pascua River (RW19-06) has a geochemical composition similar to the fjord samples from the head of Baker Channel, and those from Huemules and Bravo rivers (RW19-07 and RW19-05) to the fjord samples from the head of Martínez Channel. The sample from Baker River (RW19-04) is similar to the fjord samples from the distal part of Martínez Channel (Figure 4).

\section{Grain Size}

The river suspended sediment samples have a unimodal grainsize distribution with a mode that is consistently between 3.60 to $3.64 \mu \mathrm{m}$ (Figures $\mathbf{5 A}, \mathbf{6}$ ). The proximal fjord surface sediment samples ( $<5 \mathrm{~km}$ from the river mouth) also display a fine silt mode but its exact value $(4-7 \mu \mathrm{m})$ is consistently higher than that of the river suspended sediment samples (Figures 5B, 6). In addition, most of the proximal fjord surface sediment samples have a second mode in the medium silt to fine sand fraction $(15-100 \mu \mathrm{m}$; Figure 5B). The distal fjord surface sediment samples ( $>5 \mathrm{~km}$ from the river mouth) have a grain-size mode and distribution that are comparable to those of the river suspended sediment samples, with a mode averaging at $3.73 \pm 0.48 \mu \mathrm{m}$ (Figures 5C, 6). In the distal sections of both the Martínez and Baker channels, the grainsize mode decreases toward the Pacific Ocean, however, the grain-size mode of the most westward sample deviates from this trend (Figure 6).

\section{DISCUSSION}

\section{Magnetic Susceptibility and Inorganic Geochemistry as Provenance Tracers}

This section evaluates whether magnetic susceptibility and/or inorganic geochemistry can be used to trace sediment

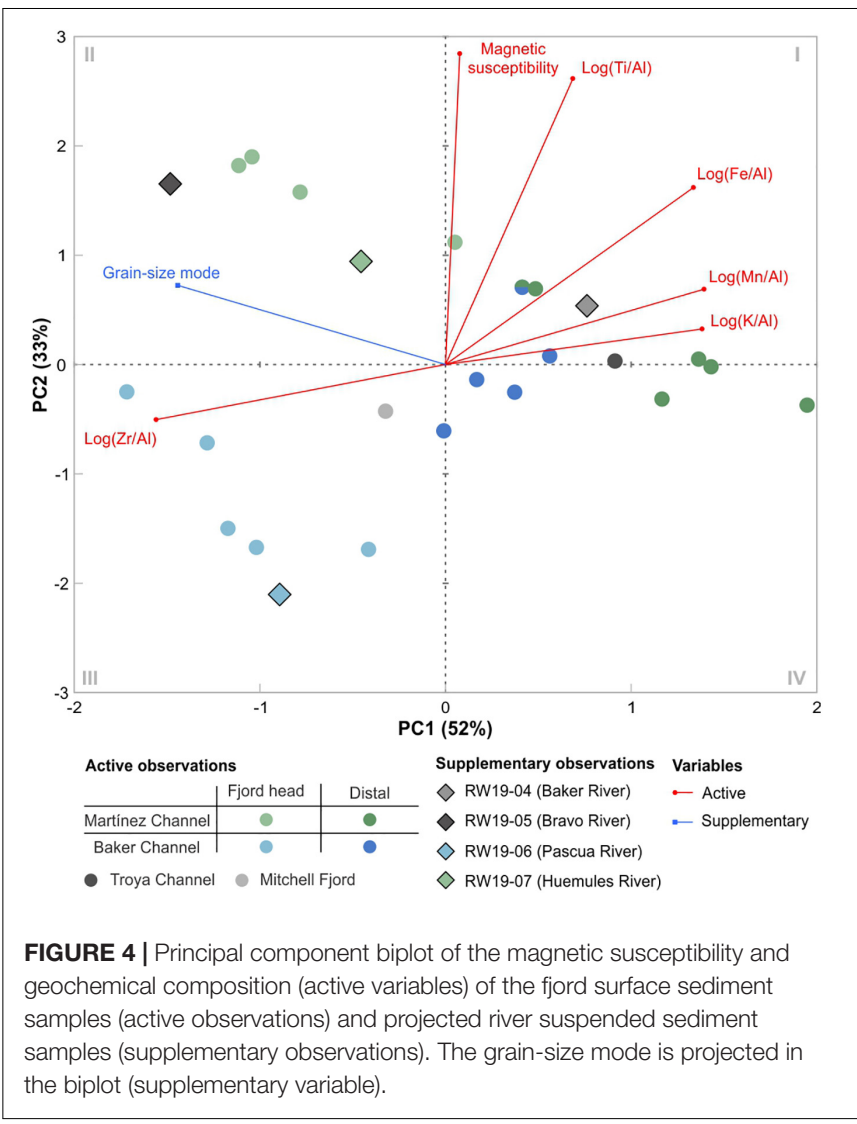

provenance, i.e., to distinguish between sediments derived from the NPI and from the SPI. In addition to analyzing the fjord surface sediment samples, the four river suspended sediment samples are considered as potential provenance endmembers, hereafter referred to as "NPI end-member" and "SPI end-member."

The first requirement for inorganic geochemical elements to work as reliable provenance indicators is the absence of biological control on their concentrations. For the surface sediment samples from the Baker-Martínez fjord system, this lack of biological control is shown by the lack of significant correlation between the Al-based log ratios of $\mathrm{Fe}, \mathrm{K}, \mathrm{Mn}, \mathrm{Ti}$, and $\mathrm{Zr}$ and organic carbon, biogenic opal and $\mathrm{CaCO}_{3}$ contents (Supplementary Table 2).

In the principal component biplot of the fjord surface sediment samples (Figure 4), the first principal component (PC1, 52\%) seems to reflect variations in distance within the fjords, to which grain size is associated. The second principal component (PC2, 33\%) differentiates the sediments at the head of Martínez Channel and Steffen Fjord from those at the head of Baker Channel and Jorge Montt Fjord. This suggests that PC2 is able to differentiate sediments of NPI origin (PC2 > 0) from sediments derived from the lithologies underlying the SPI $($ PC2 < 0). The PC2 scores of the Huemules (RW19-07) and Pascua (RW19-06) river suspended sediment samples, which represent rivers entirely fed by the NPI and SPI, respectively, confirm this differentiation (Figure 4). Therefore, we suggest 


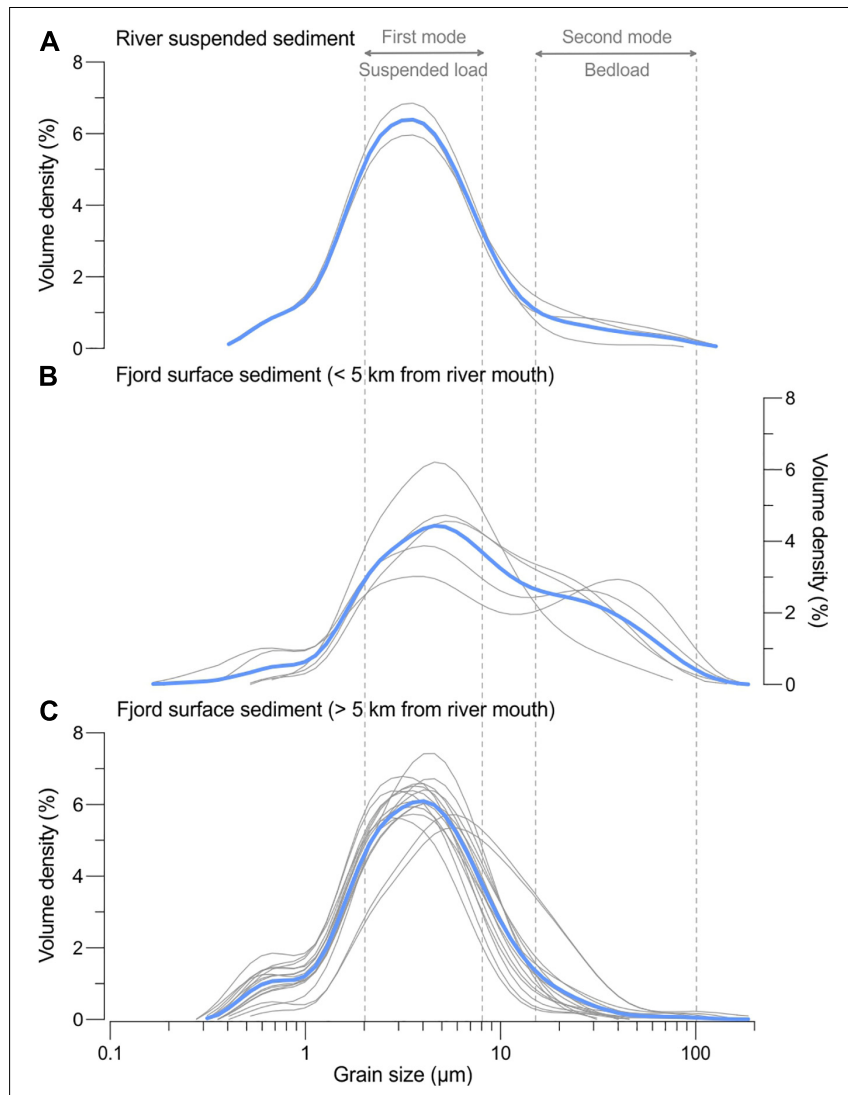

FIGURE 5 | Grain-size distributions of (A) the river suspended sediment samples, (B) the fjord surface sediment samples located less than $5 \mathrm{~km}$ from a river mouth, and $\mathbf{( C )}$ the fjord surface sediment samples located more than $5 \mathrm{~km}$ from a river mouth. The distributions shown in blue represent the average grain-size distribution of each group.

that PC2 reflects sediment provenance. The observation that magnetic susceptibility and $\log (\mathrm{Ti} / \mathrm{Al})$ both have high PC2 loadings $(\geq 0.86)$ and low PC1 loadings $(\leq 0.41)$ (Figure 4) additionally suggests that these two variables can serve as provenance tracers.

The contrast in magnetic susceptibility between sediments derived from the lithologies underlying the NPI and SPI is clearly visible in the values measured on the river suspended sediment samples and on the fjord surface sediment samples from the heads of Martínez and Baker channels (Figure 3). Samples from the rivers originating from NPI outlet glaciers (Baker River; RW19-04, and Huemules River; RW19-07) and those from the fjords in which these rivers discharge (head of Martínez Channel and Steffen Fjord) have consistently higher values than their SPI counterparts (Figure 3). This difference in magnetic susceptibility reflects the igneous nature of the bedrock underling the NPI (Patagonian Batholith) compared to that of the metamorphic basement under the SPI (Eastern Andean Metamorphic Complex). This is supported by (a) the generally higher abundance of magnetic minerals in magmatic rocks compared to metamorphosed sedimentary rocks (McEnroe et al., 2004; Direen et al., 2008), and (b) their distinct magnetic signatures on lithospheric magnetic anomaly maps (Maus et al., 2008; Michelena and Kilian, 2015). Although titanomagnetite, pyrrhotite, and ilmenite are generally considered as the main magnetic carriers in the Patagonian Batholith plutonic suite (Michelena and Kilian, 2015), it is unlikely that these dense and refractory minerals are transported in suspension in the regional rivers and fjords (Bertrand et al., 2012b). These minerals may, however, also occur as inclusions in fine-grained plagioclase (Scofield and Roggenthen, 1986; Andrews, 2008; Andrews et al., 2010), which can then be transported in suspension, as previously suggested for northern Patagonian fjord sediments (Ghazoui, 2011; Bertrand et al., 2012b). Alternatively, hornblende and biotite, which are relatively abundant in the Patagonian Batholith (Pankhurst et al., 1999; Sernageomin, 2003; Hervé et al., 2007) could also contribute to the high magnetic susceptibility of suspended sediments derived from the NPI.

As suggested by the principal component analysis results (Figure 4$), \log (\mathrm{Ti} / \mathrm{Al})$ is one of the most powerful variables to differentiate between sediments derived from the NPI and SPI. The higher $\log (\mathrm{Ti} / \mathrm{Al})$ signature of NPI-derived sediments is clearly supported by the composition of the Huemules (RW19-07) and Baker (RW19-04) river suspended sediments samples, and by that of surface sediment samples from the head of Martínez Channel and Steffen Fjord (Figure 7). Sediments derived from the SPI (RW19-06; Pascua River, and surface sediment samples from the head of Baker Channel and Jorge Montt Fjord) have consistently lower $\log (\mathrm{Ti} / \mathrm{Al})$ values (Figure 7).

The geochemical distinction between sediments derived from the NPI and SPI is most probably related to the geochemical composition of the Patagonian Batholith and Eastern Andean Metamorphic Complex lithologies that are effectively eroded to produce the river sediments transported in suspension and eventually deposited into the fjords (Figure 1 and Table 1; Liu et al., 2020). Although the Patagonian Batholith contains granite, granodiorite, diorite, tonalite, and gabbro, the geochemistry of RW19-07 (Huemules River) suggests that the composition of the Patagonian Batholith-derived sediment that reaches the Baker-Martínez fjord system is best represented by diorite and tonalite (Supplementary Figure 1A), in agreement with the occurrence of diorite and tonalite in the Baker and Huemules river watersheds (Parada et al., 1997; Pankhurst et al., 1999). This is supported by the composition of RW1904 (Baker River), which also plots among the diorite and tonalite samples (Supplementary Figure 1A). Likewise, the Eastern Andean Metamorphic Complex consists of metasandstone and -mudstone, and the geochemistry of RW1905 (Bravo River) and RW19-06 (Pascua River) suggests that the metamorphosed mudstones best represent the Eastern Andean Metamorphic Complex-derived sediment reaching the Baker-Martínez fjord system (Supplementary Figure 1B). This observation likely results from the grain size of the sediment produced by erosion of metamorphosed mudstone (fine) vs. sandstone (coarse), resulting in a higher contribution of sediment of meta-mudstone origin. Hence, we suggest that the NPI end-member is best represented by diorite and tonalite 


\section{Grain-size mode $(\mu \mathrm{m})$}

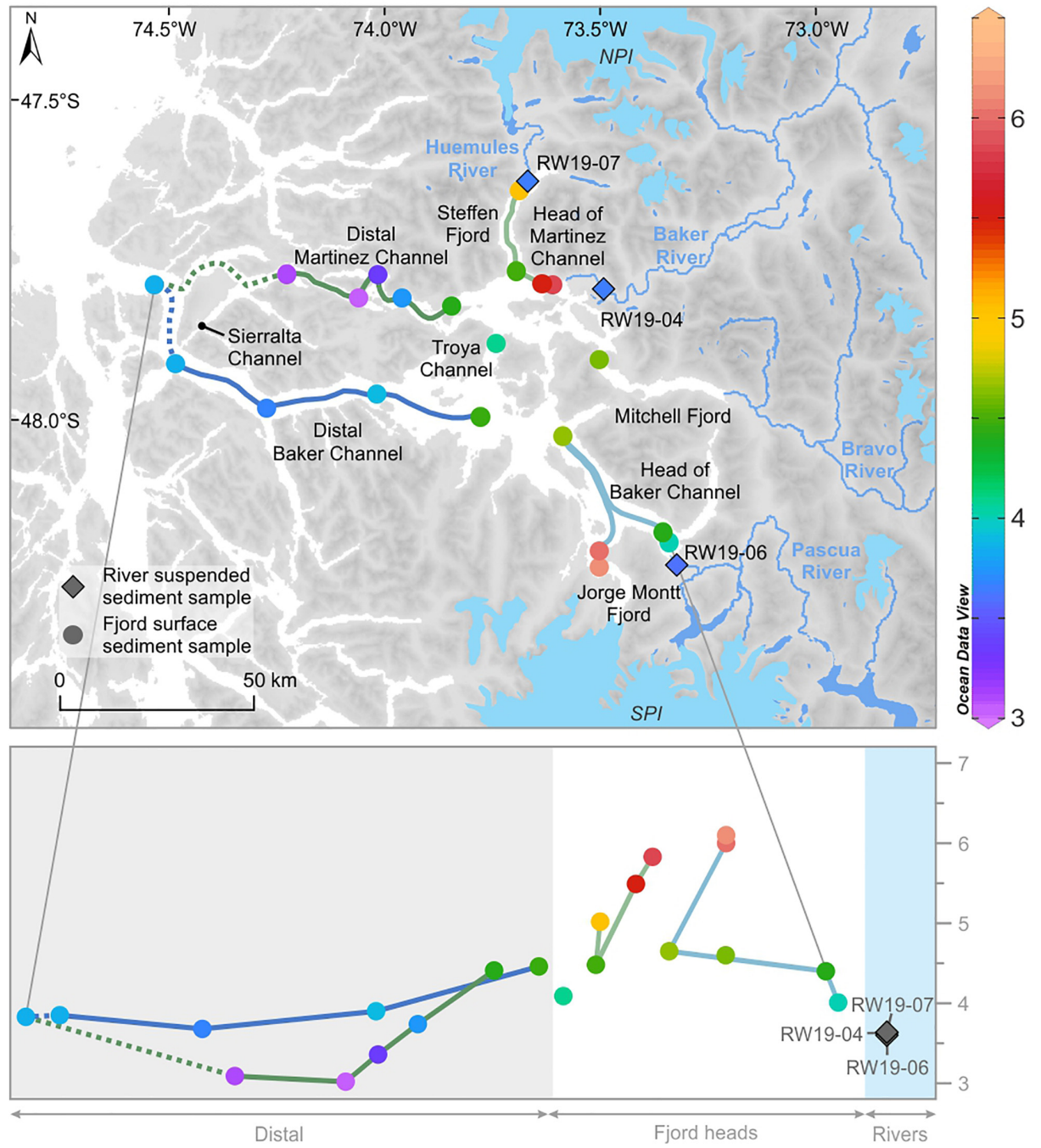

FIGURE 6 | Spatial variability in the grain-size mode of the fjord and river sediment samples. The colored lines between the fjord samples represent the four subsets with $n>1$ (Figure 2). In the bottom panel, the fjord samples are plotted according to longitude.

from the Patagonian Batholith, and the SPI end-member by metamorphosed mudstones from the Eastern Andean Metamorphic Complex.

Our results suggest that the sediment derived from the NPI is more magnetic and richer in Ti than the sediment from the SPI (Figure 8). These differences result from the nature of the bedrock effectively eroded by NPI vs. SPI glaciers (Figure 1). Since the Huemules River directly originates from the NPI, sample RW19-07 was used to define the NPI endmember. Likewise, sample RW19-06 from Pascua River was used to define the SPI end-member. Sample RW19-04 from Baker River was not used to define the NPI end-member since Baker River also drains the Eastern Andean Metamorphic Complex in the eastern non-glaciated part of the watershed (Figure 1 and Table 1; Liu et al., 2020), and is therefore not entirely representative of the NPI. Sample RW19-05 was not considered as a provenance end-member since the suspended sediment concentration in Bravo River $(1.1 \mathrm{mg} / \mathrm{L})$ is too low to accurately represent sediment transport toward the BakerMartínez fjord system.

\section{Spatial Variations in Grain Size and Its Influence on the Provenance Tracers}

In this section, we evaluate whether grain size variations limit the ability of magnetic susceptibility and inorganic geochemistry, i.e., $\log (\mathrm{Ti} / \mathrm{Al})$, to track sediment provenance throughout the BakerMartínez fjord system. To serve this purpose, the grain-size mode was projected in the principal component biplot of the fjord surface sediment samples (Figure 4). The results clearly show that grain-size mode has a strong loading on PC1 (loading $=-0.87$ ) but not on PC2 (loading $=0.24$ ), suggesting that sediment provenance across the Baker-Martínez fjord system is relatively independent of grain size variations. 


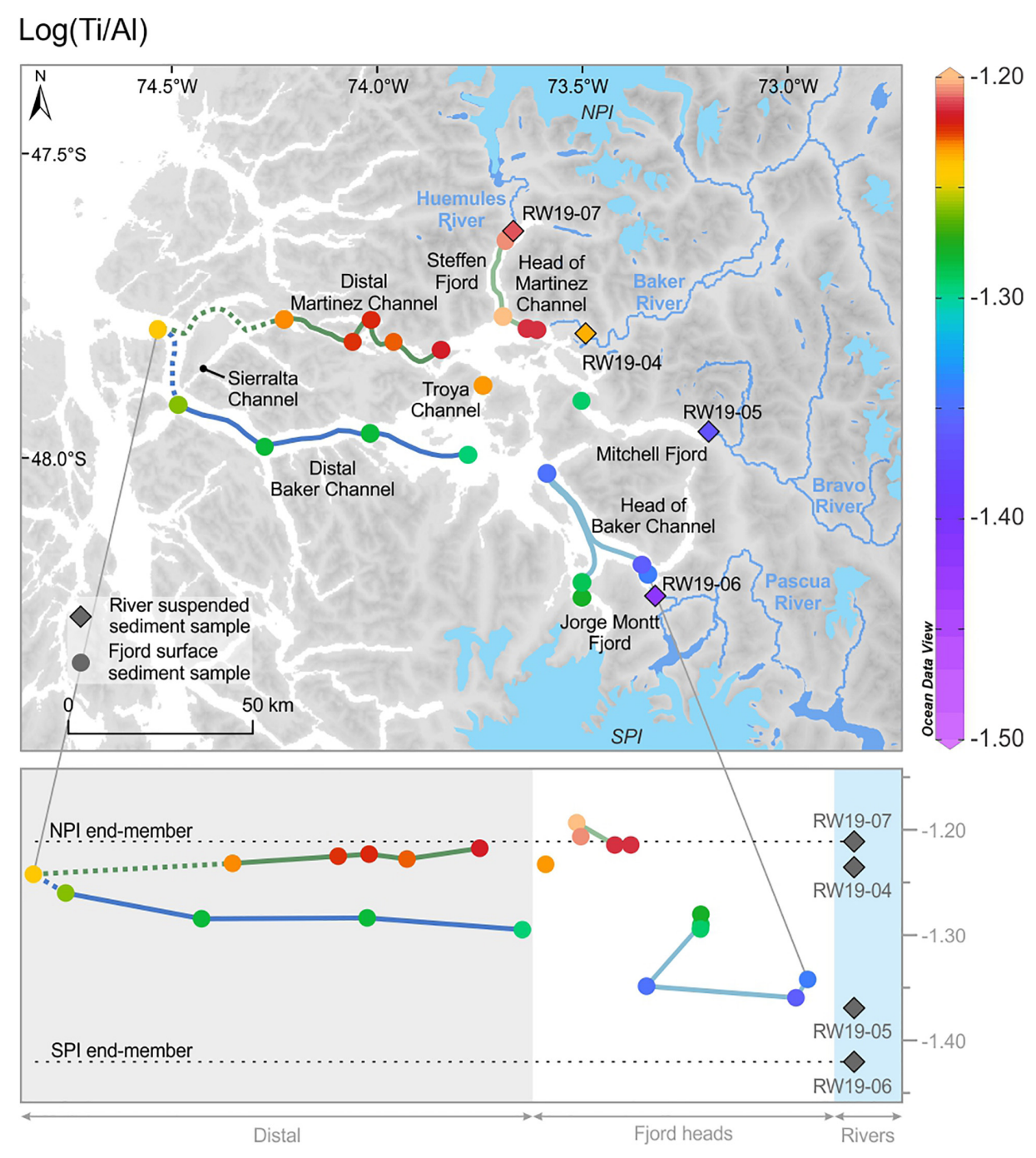

FIGURE 7 | Spatial variability in log(Ti/Al) of the fjord and river sediment samples. The colored lines between the fjord samples represent the four subsets with $n>1$ (Figure 2). In the bottom panel, the fjord samples are plotted according to longitude. Error bars are smaller than the size of the symbols. The provenance end-members are defined by the RW19-07 (NPI) and RW19-06 (SPI) river sediment samples.

Although variations in magnetic susceptibility and $\log (\mathrm{Ti} / \mathrm{Al})$ across the entire Baker-Martínez fjord system seem to reflect sediment provenance (section "Magnetic Susceptibility and Inorganic Geochemistry as Provenance Tracers"), variations in these two indicators within specific fjords appear influenced by grain size, as suggested by the spread of these samples along PC1 (Figure 4). The positive within-fjord relations between magnetic susceptibility and grain-size mode are confirmed for Martínez Channel and Steffen Fjord $(r=0.91 ; p<0.01 ; n=10)$ and for the head of Baker Channel and Jorge Montt Fjord ( $r=0.79 ; p=0.11$; $n=5$ ). In these two cases, coarser samples are more magnetic and grain size seems to be the primary factor controlling their magnetic susceptibility values, in agreement with the findings of Snowball et al. (1999), Sandgren and Snowball (2001), Bertrand et al. (2012b), Shin et al. (2020), and Piret et al. (2021). In the distal part of Baker Channel, however, the relation between magnetic susceptibility and grain-size mode is negative and insignificant ( $r=-0.68 ; p=0.21 ; n=5$ ), which suggests that, for these samples, provenance plays a more important role in determining magnetic susceptibility than grain size.

A similar influence of grain size on $\log (\mathrm{Ti} / \mathrm{Al})$ can be observed in Martínez Channel and Steffen Fjord $(r=0.62 ; p=0.05$; $n=10)$ and for the head of Baker Channel and Jorge Montt Fjord ( $r=0.92 ; p<0.05 ; n=5)$. In these two cases, $\log (\mathrm{Ti} / \mathrm{Al})$ is positively correlated with grain-size mode, in agreement with the results of Bertrand et al. (2012b) who suggest that $\mathrm{Ti} / \mathrm{Al}$ in Patagonian fjord sediments is primarily controlled by grain size and hydrodynamic sorting of minerals. As with magnetic susceptibility, the relation between $\log (\mathrm{Ti} / \mathrm{Al})$ and grain-size mode is weakly negative and insignificant in the distal part of Baker Channel $(r=-0.48, p=0.41 ; n=5)$, where grain size is relatively stable (Figure 6). This again suggests that, in the distal 


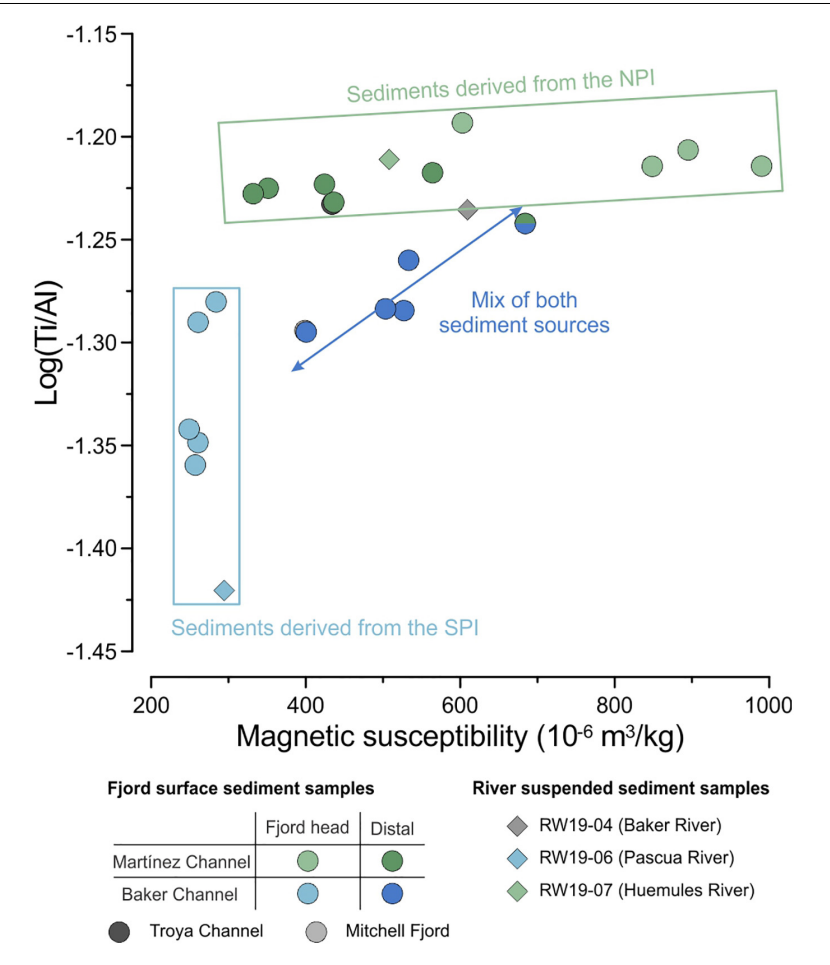

FIGURE 8 | Log(Ti/Al) vs. magnetic susceptibility of the fjord and river sediment samples. The green and blue rectangles represent sediments derived from the Northern (NPI) and Southern (SPI) Patagonian Icefields, respectively. RW19-05 is considered as an outlier (RESULTS section "Magnetic Susceptibility") and was thus not included. Error bars are smaller than the size of the symbols.

part of Baker Channel, provenance plays a more important role than grain size in controlling $\log (\mathrm{Ti} / \mathrm{Al})$.

To summarize, within fjords fed by meltwater from one icefield, such as Martínez Channel, the head of Baker Channel and Steffen and Jorge Montt fjords, magnetic susceptibility and $\log (\mathrm{Ti} / \mathrm{Al})$ are controlled by grain size. However, in fjords where sediments are derived from both icefields, i.e., the distal part of Baker Channel, magnetic susceptibility and $\log (\mathrm{Ti} / \mathrm{Al})$ are primarily driven by sediment provenance.

\section{Sediment Provenance Quantification}

Throughout the distal part of Baker Channel, magnetic susceptibility and $\log (\mathrm{Ti} / \mathrm{Al})$ of the fjord surface sediment samples increase westward (Figures 3, 7), from values roughly halfway between the end-members toward values similar to the NPI end-member, whereas the grain-size mode decreases by $\sim 1 \mu \mathrm{m}$ (Figure 6). These increasing trends can only be explained by the mixing, in different proportions, of sediments derived from the NPI and SPI.

A linear mixing model based on $\log (\mathrm{Ti} / \mathrm{Al})$, with RW1907 (Huemules River) and RW19-06 (Pascua River) as NPI and SPI end-members, was applied to quantitatively estimate the NPI vs. SPI sediment contributions to the distal part of Baker Channel (Figure 9). Magnetic susceptibility was not included in the model since the samples in the distal part of Baker Channel exceed the end-member limits (Figure 3), suggesting that factors other than provenance influence the exact magnetic susceptibility values. Therefore, the ability of magnetic susceptibility to differentiate between sediments derived from the NPI and SPI remains qualitative.

The provenance quantification results suggest that the fjord sediment samples from the distal part of Baker Channel derive from both the NPI and SPI, and that the NPI is the dominant source (60-85\%) throughout the fjord (Figure 9). The higher relative input of NPI-derived sediment is in agreement with (1) the larger drainage area of the Huemules and lower Baker river watersheds, which are the main contributors of NPI-related sediment to the Baker-Martínez fjord system, compared to the lower Pascua River watershed and Jorge Montt Glacier (Table 1), (2) the higher combined mean annual discharge of Huemules $\left(121 \mathrm{~m}^{3} / \mathrm{s}\right)$ and Baker $\left(1,133 \mathrm{~m}^{3} / \mathrm{s}\right)$ rivers vs. Pascua River $\left(753 \mathrm{~m}^{3} / \mathrm{s}\right)$ and Jorge Montt Glacier $\left(129 \mathrm{~m}^{3} / \mathrm{s}\right.$ ) (Pantoja et al., 2011; Pryer et al., 2020), (3) the higher suspended sediment concentrations in Huemules $(57.2 \mathrm{mg} / \mathrm{L})$ and Baker $(35.8 \mathrm{mg} / \mathrm{L})$ rivers compared to Pascua River (5.2 mg/L), and (4) the satellitederived average spring-summer suspended sediment distribution throughout the Baker-Martínez fjord system (Figure 2).

The provenance quantification also suggests that the proportion of NPI-derived sediments increases westward from 60 to $85 \%$ throughout the distal part of Baker Channel (Figure 9). The first location at which mixing between the two sources can occur is around Troya Channel, probably slightly to the west of station St8, as suggested by the surface turbidity map (Figure 2). The high amount of NPI-derived sediments at St8 and St7 suggests the presence of an effective southward transport of suspended sediments from Martínez Channel to Baker Channel, especially in summer when river discharge and suspended sediment concentrations are maximum (Aiken, 2012; Amann et al., Submitted). Although the proportion of NPI vs. SPIderived sediment does not significantly change between stations St8 and St6, the proportion of NPI-derived sediment increases to about $80 \%$ at stations St5 and St4, suggesting an additional input of NPI-derived sediment via Sierralta Channel and the western end of Martínez Channel (Figure 9), in agreement with variations in surface turbidity values (Figure 2).

It is worth mentioning that the proportions of NPI and SPI-derived sediments shown in Figure 9 are relative, i.e., an increase in sediment input from one of the sources results in an apparent decrease in the contribution of the other source. This comment is valid for both spatial changes inferred from surface sediment samples, and for temporal changes inferred from sediment cores. Interpreting changes in sediment provenance to the distal part of Baker Channel through time therefore requires considering possible changes in the two sources. In addition, an increase in the input of sediments derived from the Eastern Andean Metamorphic Complex could also be caused by processes independent of meltwater input, such as intense precipitation in the eastern part of the lower Baker River watershed (Figure 1). This would complicate the interpretation of the provenance tracers in terms of variations in meltwater input since sediment derived from the eastern part of the lower Baker River watershed is compositionally similar to SPI-derived sediments. 


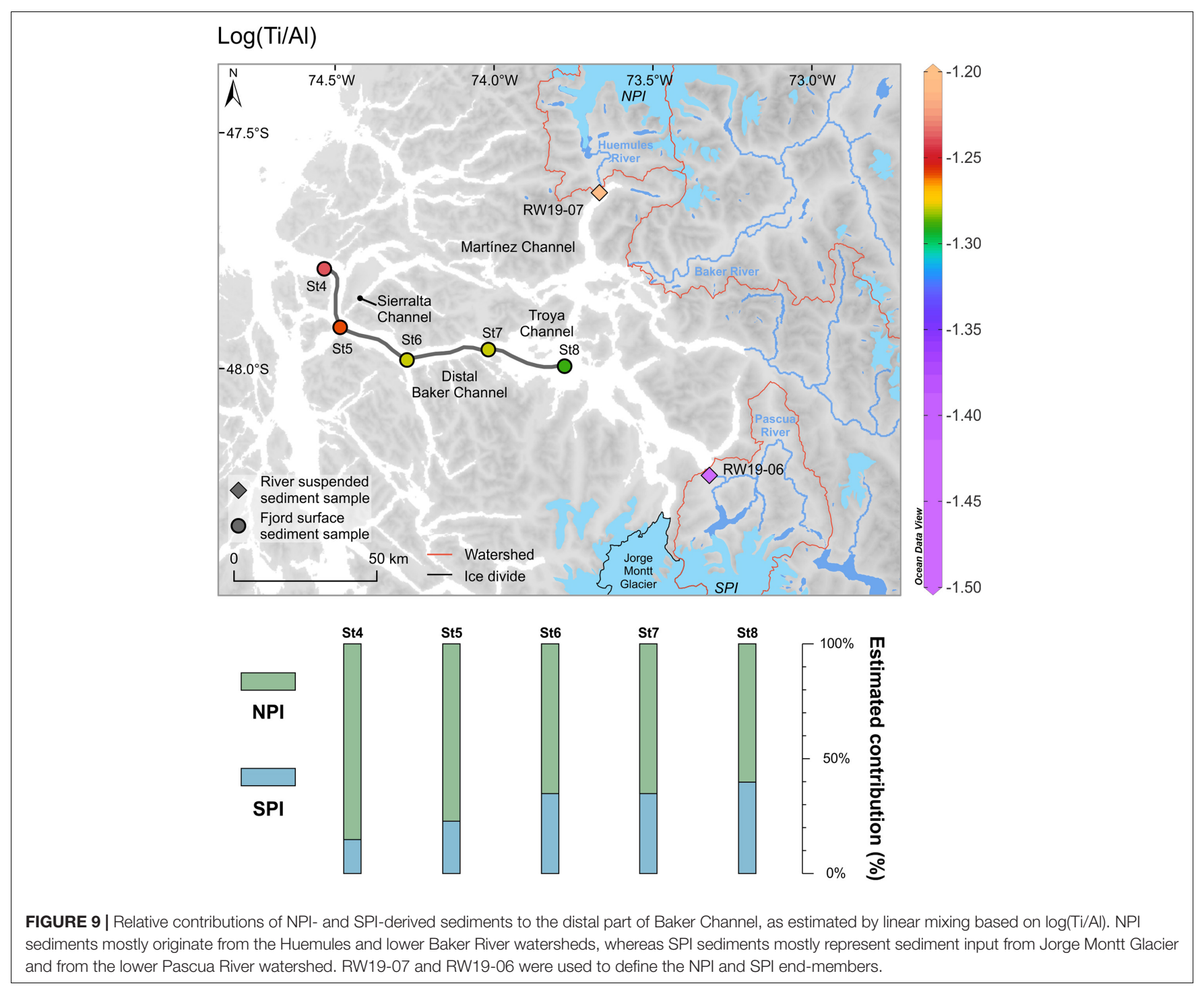

A limitation of our study is that the sediment end-members were entirely defined using single river suspended sediment samples collected in summer. Although summer corresponds to the peak in meltwater contribution and sediment input (Amann et al., Submitted), this characterization of the sediment sources does not take into account the possible seasonal changes in the composition of the sediment reaching the fjords. The good agreement between the composition of the river suspended sediments and that of the fjord surface sediment samples from the heads of Martínez and Baker channels, which represent yearround sedimentation (Figure 7), however, suggests that seasonal variations in sediment composition are limited and/or that most of the fjord sediments are supplied during the meltwater season in summer. Collecting river suspended sediment samples during all four seasons and over multiple years could contribute to a more accurate definition of the end-members, and ultimately to a more robust quantitative mixing model. The magnetic and geochemical contrasts between the end-members, however, are unlikely to change since they reflect the clear lithological differences that characterize the NPI vs. SPI watersheds.

\section{CONCLUSION}

Our results suggest that magnetic susceptibility and $\log (\mathrm{Ti} / \mathrm{Al})$ can be used as provenance tracers to differentiate NPI- from SPIderived sediments throughout the Baker-Martínez fjord system, but that only $\log (\mathrm{Ti} / \mathrm{Al})$ can provide quantitative estimates of the proportions of sediment derived from each icefield. The ability of these tracers to distinguish between sediment derived from each icefield reflects the high magnetic susceptibility and Ti content of the igneous rocks underlying the NPI, compared to the weakly magnetic and Ti-poor metamorphic bedrock that underlies the SPI. Within fjords fed by meltwater from only one icefield, e.g., Martínez Channel, the head of Baker Channel and Steffen and Jorge Montt fjords, variations in magnetic susceptibility and $\log (\mathrm{Ti} / \mathrm{Al})$ are mostly driven by changes in grain size, which in turn reflect the progressive settling of sediment from the hypopycnal plume. In fjords receiving sediments from both icefields, such as the distal part of Baker Channel, magnetic susceptibility and $\log (\mathrm{Ti} / \mathrm{Al})$ can serve as qualitative and quantitative tracers of sediment provenance, respectively. 
We suggest that $\log (\mathrm{Ti} / \mathrm{Al})$, and to a lesser extent magnetic susceptibility, can be applied to long sediment cores from the Baker-Martínez fjord system to reconstruct relative variations in sediment input from each icefield, which may in turn be interpreted as changes in river discharge and/or glacier mass balance. To do so, sediment cores must come from a fjord receiving sediment from both sources, such as the distal part of Baker Channel, and grain size must remain relatively stable. Although the results presented here are specific to the Baker-Martínez fjord system, they suggest that cost-effective parameters such as sediment inorganic geochemistry, can be used to reconstruct sediment provenance with a relatively good precision, if the main processes affecting the concentration of each element are adequately understood.

\section{DATA AVAILABILITY STATEMENT}

The original contributions presented in the study are included in the article/Supplementary Material, further inquiries can be directed to the corresponding author.

\section{AUTHOR CONTRIBUTIONS}

MT conducted all laboratory analyses on the fjord surface sediment samples, processed the data, interpreted the results, and wrote the manuscript. SB designed this study, obtained funding, led the field expedition during which the river suspended sediment samples were collected, coordinated the collaborative research activities, and wrote the manuscript with MT. BA and DL collected the river suspended sediment samples and measured river suspended sediment concentrations. BA analyzed the grain size, magnetic susceptibility, and inorganic geochemistry of the river suspended sediment samples together with MT. JP provided the CIMAR 20 Fiordos samples. CL co-organized the COPAS Sur-Austral 2014 cruise and provided the CO14 fjord samples.

\section{REFERENCES}

Aiken, C. M. (2012). Seasonal thermal structure and exchange in Baker Channel. Chile. Dynamics Atmospheres Oceans 58, 1-19. doi: 10.1016/j.dynatmoce.2012. 07.001

Amann, B., Bertrand, S., Garreton, C. A., and Reid, B. (Submitted). Seasonal variations in the origin of river sediments (Baker River, Chile, $48^{\circ} \mathrm{S}$ ): a prerequisite for climate and hydrological reconstructions. J. Geophys. Res.: Earth Surface

Andrews, J. T. (2008). The role of the Iceland Ice Sheet in the North Atlantic during the late Quaternary: a review and evidence from Denmark Strait. J. Quaternary Sci. 23, 3-20. doi: 10.1002/jqs.1142

Andrews, J. T., Jennings, A. E., Coleman, G. C., and Eberl, D. D. (2010). Holocene variations in mineral and grain-size composition along the East Greenland glaciated margin $\left(\mathrm{ca} 67^{\circ}-70^{\circ} \mathrm{N}\right)$ : local versus long-distance sediment transport. Quaternary Sci. Rev. 29, 2619-2632. doi: 10.1016/j.quascirev.2010. 06.001

Augustsson, C., and Bahlburg, H. (2003). Active or passive continental margin? Geochemical and Nd isotope constraints of metasediments in the backstop of a pre-Andean accretionary wedge in southernmost Chile $\left(46^{\circ} 30^{\prime}-48^{\circ} 30^{\prime} \mathrm{S}\right)$. Geol. Soc. Lond. Special Publications 208, 253-268. doi: 10.1144/GSL.SP.2003.208. 01.12
All authors contributed to the interpretation of the results and to the writing of the manuscript, and all approved the final version.

\section{FUNDING}

This research was funded by the UGent project HYDROPROX (01N02216). Some of the sediment samples used in this study were collected with funding from the Chilean National Oceanographic Committee (CONA Grant C20F1404) and from the COPAS Sur-Austral Center.

\section{ACKNOWLEDGMENTS}

We thank the captain and crew of the R/V Sur-Austral for their help during sample collection and Lorena Rebolledo for splitting the CO14 samples. We are grateful to Dr. Charles Nittrouer (University of Washington, School of Oceanography and Department of Earth and Space Sciences) and to Dr. Carlos Moffat (University of Delaware) for collecting JM1 and JM7, and to Ellen De Wilde for analyzing the grain size and magnetic susceptibility of these samples. We also thank the PISCES team from the University of Bristol for providing the PI-FC17-S8 sediment core, Loic Piret for his help during RW19 sample collection and for constructive discussions, Veerle Vandenhende for operating the ICP-AES, and Dr. Elke Vandekerkhove for providing valuable suggestions on an earlier version of this manuscript. This work was part of the first author's MSc thesis at Ghent University.

\section{SUPPLEMENTARY MATERIAL}

The Supplementary Material for this article can be found online at: https://www.frontiersin.org/articles/10.3389/fmars. 2021.612309/full\#supplementary-material

Bertrand, S., Hughen, K., Sepúlveda, J., and Pantoja, S. (2014). Late Holocene covariability of the southern westerlies and sea surface temperature in northern Chilean Patagonia. Quaternary Sci. Rev. 105, 195-208. doi: 10.1016/j.quascirev. 2014.09.021

Bertrand, S., Hughen, K. A., Lamy, F., Stuut, J. B., Torrejon, F., and Lange, C. B. (2012a). Precipitation as the main driver of Neoglacial fluctuations of Gualas glacier, Northern Patagonian Icefield. Clim. Past 8, 519-534. doi: 10.5194/cp-8519-2012

Bertrand, S., Hughen, K. A., Sepúlveda, J., and Pantoja, S. (2012b). Geochemistry of surface sediments from the fjords of Northern Chilean Patagonia (44$47^{\circ} \mathrm{S}$ ): spatial variability and implications for paleoclimate reconstructions. Geochim. Cosmochim. Acta 76, 125-146. doi: 10.1016/j.gca.2011. 10.028

Bertrand, S., Lange, C. B., Pantoja, S., Hughen, K., Van Tornhout, E., and Wellner, J. S. (2017). Postglacial fluctuations of Cordillera Darwin glaciers (southernmost Patagonia) reconstructed from Almirantazgo fjord sediments. Quaternary Sci. Rev. 177, 265-275. doi: 10.1016/j.quascirev.2017.10.029

Bianchi, T. S., Arndt, S., Austin, W. E. N., Benn, D. I., Bertrand, S., Cui, X., et al. (2020). Fjords as aquatic critical zones (ACZs). Earth-Sci. Rev. 203:103145. doi: 10.1016/j.earscirev.2020.103145

Bloemsma, M. R., Zabel, M., Stuut, J. B. W., Tjallingii, R., Collins, J. A., and Weltje, G. J. (2012). Modelling the joint variability of grain size and chemical 
composition in sediments. Sedimentary Geol. 280, 135-148. doi: 10.1016/j. sedgeo.2012.04.009

Boex, J., Fogwill, C., Harrison, S., Glasser, N. F., Hein, A., Schnabel, C., et al. (2013). Rapid thinning of the late Pleistocene Patagonian Ice Sheet followed migration of the Southern Westerlies. Sci. Rep. 3:2118. doi: 10.1038/srep02118

Boisier, J. P., Alvarez-Garretón, C., Cepeda, J., Osses, A., Vásquez, N., and Rondanelli, R. (2018). CR2MET: a high-resolution precipitation and temperature dataset for hydroclimatic research in Chile. Geophys. Res. Abstracts 20:19739.

Boldt, K. V. (2014). Fjord Sedimentation During the Rapid Retreat of Tidewater Glaciers: Observations and Modeling. Ph.D. thesis, Washington, WA: University of Washington.

Bonneau, L., Toucanne, S., Bayon, G., Jorry, S. J., Emmanuel, L., and Silva Jacinto, R. (2017). Glacial erosion dynamics in a small mountainous watershed (Southern French Alps): a source-to-sink approach. Earth Planetary Sci. Lett. 458, 366-379. doi: 10.1016/j.epsl.2016.11.004

Boyle, J. F. (2001). "Inorganic geochemical methods in paleolimnology," in Tracking Environmental Change Using Lake Sediments Volume 2: Physical and Geochemical Methods, eds W. M. Last and J. P. Smol (Dordrecht: Kluwer Academic Publishers), 83-141.

Calvert, S. E., Pedersen, T. F., and Karlin, R. E. (2001). Geochemical and isotopic evidence for post-glacial palaeoceanographic changes in Saanich Inlet, British Columbia. Mar. Geol. 174, 287-305. doi: 10.1016/S0025-3227(00) 00156-0

Caniupán, M., Lamy, F., Lange, C. B., Kaiser, J., Kilian, R., Arz, H. W., et al. (2014). Holocene sea-surface temperature variability in the Chilean fjord region. Quaternary Res. 82, 342-353. doi: 10.1016/j.yqres.2014.07.009

Cowan, E. A., and Powell, R. D. (1990). Suspended sediment transport and deposition of cyclically interlaminated sediment in a temperate glacial fjord, Alaska, U.S.A. Geol. Soc. Lond. Special Publications 53, 75-89. doi: 10.1144/GSL. SP.1990.053.01.04

Davies, B. J., Darvill, C. M., Lovell, H., Bendle, J. M., Dowdeswell, J. A., Fabel, D., et al. (2020). The evolution of the Patagonian Ice Sheet from $35 \mathrm{ka}$ to the present day (PATICE). Earth-Sci. Rev. 204:103152. doi: 10.1016/j.earscirev.2020. 103152

Direen, N. G., Pfeiffer, K. M., and Schmidt, P. W. (2008). Strong remanent magnetization in pyrrhotite: a structurally controlled example from the Paleoproterozoic Tanami orogenic gold province, northern Australia. Precambrian Res. 165, 96-106. doi: 10.1016/j.precamres.2008.05.007

Dussaillant, J. A., Buytaert, W., Meier, C., and Espinoza, F. (2012). Hydrological regime of remote catchments with extreme gradients under accelerated change: the Baker basin in Patagonia. Hydrological Sci. J. 57, 1530-1542. doi: 10.1080/ 02626667.2012.726993

Faúndez, V., Hervé, F., and Lacassie, J. P. (2002). Provenance and depositional setting of pre-Late Jurassic turbidite complexes in Patagonia. Chile. N. Z. J. Geol. Geophys. 45, 411-425. doi: 10.1080/00288306.2002.9514982

Faust, J. C., Knies, J., Slagstad, T., Vogt, C., Milzer, G., and Giraudeau, J. (2014). Geochemical composition of Trondheimsfjord surface sediments: sources and spatial variability of marine and terrigenous components. Continental Shelf Res. 88, 61-71. doi: 10.1016/j.csr.2014.07.008

Fick, S. E., and Hijmans, R. J. (2017). WorldClim 2: new 1-km spatial resolution climate surfaces for global land areas. Int. J. Climatol. 37, 4302-4315. doi: $10.1002 /$ joc. 5086

Fontijn, K., Lachowycz, S. M., Rawson, H., Pyle, D. M., Mather, T. A., Naranjo, J. A., et al. (2014). Late Quaternary tephrostratigraphy of southern Chile and Argentina. Quaternary Sci. Rev. 89, 70-84. doi: 10.1016/j.quascirev.2014. 02.007

Foresta, L., Gourmelen, N., Weissgerber, F., Nienow, P., Williams, J. J., Shepherd, A., et al. (2018). Heterogeneous and rapid ice loss over the Patagonian Ice Fields revealed by CryoSat-2 swath radar altimetry. Remote Sensing Environ. 211, 441-455. doi: 10.1016/j.rse.2018.03.041

Garreaud, R., Lopez, P., Minvielle, M., and Rojas, M. (2013). Large-Scale control on the patagonian climate. J. Clim. 26, 215-230. doi: 10.1175/JCLI-D-12-00001.1

Ghazoui, Z. (2011). Sédimentation Récente Dans les Fjords de Patagonie Chilienne: Caractérisation des Sources Sédimentaires et Implication Pour la Reconstitution des Changements Environnementaux au Cours de l'Holocène. Master's thesis, Brussels, BE: Université Libre de Bruxelles.
Gómez, J., Schobbenhaus, C., and Montes, N. E. (2019). Geological Map of South America 2019. Scale 1:5 000 000. Commission for the Geological Map of the World (CGMW), Colombian Geological Survey and Geological Survey of Brazil. Paris: Colombian Geological Survey and Geological Survey of Brazil.

González, H. E., Castro, L. R., Daneri, G., Iriarte, J. L., Silva, N., Tapia, F., et al. (2013). Land-ocean gradient in haline stratification and its effects on plankton dynamics and trophic carbon fluxes in Chilean Patagonian fjords (47-50 S). Prog. Oceanogr. 119, 32-47. doi: 10.1016/j.pocean.2013. 06.003

Hervé, F., Calderón, M., and Faúndez, V. (2008). The metamorphic complexes of the Patagonian and Fuegian Andes. Geol. Acta 6, 43-53.

Hervé, F., Pankhurst, R. J., Fanning, C. M., Calderon, M., and Yaxley, G. M. (2007). The South Patagonian batholith: $150 \mathrm{my}$ of granite magmatism on a plate margin. Lithos 97, 373-394.doi: 10.1016/j.lithos.2007.01.007

HidroAysén. (2010). HidroAysén - Centrales Hidroeléctricas de Aysén S.A. Caracterización del Régimen Sedimentológico y Efectos de la Construcción de Centrales PHA. HidroAysén, 687.

Hogan, K. A., Jakobsson, M., Mayer, L., Reilly, B. T., Jennings, A. E., Stoner, J. S., et al. (2020). Glacial sedimentation, fluxes and erosion rates associated with ice retreat in Petermann Fjord and Nares Strait, north-west Greenland. Cryosphere 14, 261-286. doi: 10.5194/tc-14-261-2020

International Initiative on Water Quality [IIWQ] (2019). World Water Quality Information and Capacity Building Portal (Source: UNESCO, powered by EOMAP 2017-2019). Available online at: worldwaterquality.org.

Kaiser, J., Lamy, F., and Hebbeln, D. (2005). A 70-kyr sea surface temperature record off southern Chile (Ocean Drilling Program Site 1233). Paleoceanography 20, 1-15. doi: 10.1029/2005PA001146

Kaplan, M. R., Douglass, D. C., Singer, B. S., Ackert, R. P., and Caffee, M. W. (2005). Cosmogenic nuclide chronology of pre-last glacial maximum moraines at Lago Buenos Aires, $46^{\circ} \mathrm{S}$. Argentina. Quaternary Res. 63, 301-315. doi: 10. 1016/j.yqres.2004.12.003

Kilian, R., and Lamy, F. (2012). A review of Glacial and Holocene paleoclimate

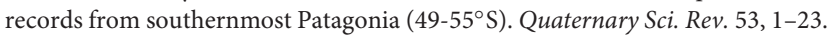
doi: 10.1016/j.quascirev.2012.07.017

Klump, J., Hebbeln, D., and Wefer, G. (2000). The impact of sediment provenance on barium-based productivity estimates. Mar. Geol. 169, 259-271. doi: 10.1016/ S0025-3227(00)00092-X

Lamy, F., Hebbeln, D., Röhl, U., and Wefer, G. (2001). Holocene rainfall variability in Southern Chile: a marine record of latitudinal shifts of the Southern Westerlies. Earth Planetary Sci. Lett. 185, 369-382. doi: 10.1016/ S0012-821X(00)00381-2

Lamy, F., Kilian, R., Arz, H. W., Francois, J., Kaiser, J., and Prange, M. (2010). Holocene changes in the position and intensity of the southern westerly wind belt. Nat. Geosci. 3, 695-699. doi: 10.1038/ngeo959

Lara, A., Bahamondez, A., González-Reyes, A., Muñoz, A. A., Cuq, E., and RuizGómez, C. (2015). Reconstructing streamflow variation of the Baker River from tree-rings in Northern Patagonia since 1765. J. Hydrol. 529, 511-523. doi: 10.1016/j.jhydrol.2014.12.007

Liguori, B. T. P., De Almeida, M. G., and De Rezende, C. E. (2016). Barium and its importance as an indicator of (Paleo) productivity. Anais Academia Brasileira Ciências 88, 2093-2103. doi: 10.1590/0001-3765201620 140592

Lipp, A. G., Shorttle, O., Syvret, F., and Roberts, G. G. (2020). Major-element composition of sediments in terms of weathering and provenance: implications for crustal recycling. Geochem. Geophys. Geosyst. 21:e2019GC008758. doi: 10. 1029/2019GC008758

Liu, D., Bertrand, S., Villaseñor, T., Van Dijck, T., Fagel, N., and Mattielli, N. (2020). Provenance of northwestern Patagonian river sediments $\left(44-48^{\circ} \mathrm{S}\right)$ : a critical evaluation of mineralogical, geochemical and isotopic tracers. Sedimentary Geol. 408:105744. doi: 10.1016/j.sedgeo.2020.105744

Liu, D., Bertrand, S., and Weltje, G. J. (2019). An empirical method to predict sediment grain size from inorganic geochemical measurements. Geochem. Geophys. Geosyst. 20, 3690-3704. doi: 10.1029/2018GC0 08154

Maus, S., Yin, F., Lühr, H., Manoj, C., Rother, M., Rauberg, J., et al. (2008). Resolution of direction of oceanic magnetic lineations by the sixth-generation lithospheric magnetic field model from CHAMP satellite 
magnetic measurements. Geochem. Geophys. Geosyst. 9:Q07021. doi: 10.1029/ 2008GC001949

McEnroe, S., Brown, L., and Robinson, P. (2004). Earth analog for Martian magnetic anomalies: remanence properties of hemo-ilmenite norites in the Bjerkreim-Sokndal intrusion. Rogaland, Norway. J. Appl. Geophys. 56, 195-212. doi: 10.1016/S0926-9851(04)00052-7

McLennan, S. M., Bock, B., Hemming, S. R., Hurowitz, J. A., Lev, S. M., and McDaniel, D. K. (2003). "The roles of provenance and sedimentary processes in the geochemistry of sedimentary rocks," in Geochemistry of Sediments and Sedimentary Rocks: Evolution Considerations to Mineral Deposit-Forming Environments, ed. D. R. Lentz (Newfoundland: Geological Association of Canada, GeoText 4, St. John's), 7-38.

Mernild, S. H., Liston, G. E., Hiemstra, C., and Wilson, R. (2017). The Andes Cordillera. Part III: glacier surface mass balance and contribution to sea level rise (1979-2014). Int. J. Climatol. 37, 3154-3174. doi: 10.1002/joc.4907

Meyer, I., Davies, G. R., and Stuut, J.-B. W. (2011). Grain size control on Sr$\mathrm{Nd}$ isotope provenance studies and impact on paleoclimate reconstructions: an example from deep-sea sediments offshore NW Africa. Geochem. Geophys. Geosyst. 12:Q03005. doi: 10.1029/2010GC003355

Michelena, M. D., and Kilian, R. (2015). Magnetic signatures of the orogenic crust of the Patagonian Andes with implication for planetary exploration. Phys. Earth Planetary Interiors 248, 35-54. doi: 10.1016/j.pepi.2015. 08.005

Moffat, C., Tapia, F. J., Nittrouer, C. A., Hallet, B., Bown, F., Boldt, K. L., et al. (2018). Seasonal evolution of ocean heat supply and freshwater discharge from a rapidly retreating tidewater glacier: jorge montt. Patagonia. J. Geophys. Res.: Oceans 123, 4200-4223. doi: 10.1002/2017JC013069

Murray, R. W., Miller, D. J., and Kryc, K. A. (2000). Analysis of Major and Trace Elements in Rocks, Sediments, and Interstitial Waters by Inductively Coupled Plasma-Atomic Emission Spectrometry (ICP-AES). ODP Technical Note 29. 27.

Pankhurst, R. J., Weaver, S. D., Hervé, F., and Larrond, P. (1999). MesozoicCenozoic evolution of the North Patagonian Batholith in Aysen, southern Chile. J. Geol. Soc. 156, 673-694. doi: 10.1144/gsigs.156.4.0673

Pantoja, S., Iriarte, L., and Daneri, G. (2011). Oceanography of the Chilean Patagonia. Continental shelf Res. 31, 149-153. doi: 10.1016/j.csr.2010. 10.013

Parada, M. A., Palacios, C., and Lahsen, A. (1997). Jurassic extensional tectonomagmatism and associated mineralization of the El Faldeo polymetallic district, Chilean Patagonia: geochemical and isotopic evidence of crustal contribution. Mineralium Deposita 32, 547-554. doi: 10.1007/s001260050121

Pérez-Santos, I., Garcés-Vargas, J., Schneider, W., Ross, L., Parra, S., and ValleLevinson, A. (2014). Double-diffusive layering and mixing in Patagonian fjords. Prog. Oceanogr. 129, 35-49. doi: 10.1016/j.pocean.2014.03.012

Piret, L., Bertrand, S., Hawkings, J., Kylander, M. E., Torrejón, F., Amann, B., et al. (2021). High-resolution fjord sediment record of a receding glacier with growing intermediate proglacial lake (Steffen Fjord, Chilean Patagonia). Earth Surface Processes Landforms 46, 239-251. doi: 10.1002/esp.5015

Piret, L., Bertrand, S., Kissel, C., De Pol-Holz, R., Tamayo Hernando, A., and Van Daele, M. (2018). First evidence of a mid-Holocene earthquake-triggered megaturbidite south of the Chile Triple Junction. Sedimentary Geol. 375, 120 133. doi: 10.1016/j.sedgeo.2018.01.002

Powell, R. D., and Molnia, B. F. (1989). Glacimarine sedimentary processes, facies and morphology of the south-southeast Alaska shelf and fjords. Mar. Geol. 85, 359-390. doi: 10.1016/0025-3227(89)90160-6

Pryer, H. V., Hawkings, J. R., Wadham, J. L., Robinson, L. F., Hendry, K. R., Hatton, J. E., et al. (2020). The influence of glacial cover on riverine silicon and iron exports in Chilean Patagonia. Glob. Biogeochem. Cycles 34:e2020GB006611. doi: 10.1029/2020GB006611

Raitzsch, M., Dueñas-Bohórquez, A., Reichart, G. J., de Nooijer, L. J., and Bickert, T. (2010). Incorporation of $\mathrm{Mg}$ and $\mathrm{Sr}$ in calcite of cultured benthic foraminifera: impact of calcium concentration and associated calcite saturation state. Biogeosciences 7, 869-881. doi: 10.5194/bg-7-869-2010

Rebolledo, L., Bertrand, S., Lange, C. B., Tapia, F. J., Quiroga, E., Troch, M., et al. (2019). Compositional and biogeochemical variations of sediments across the terrestrial-marine continuum of the Baker-Martínez fjord system (Chile, $48^{\circ}$ S). Progr. Oceanogr. 174, 89-104. doi: 10.1016/j.pocean.2018. 12.004
Revel-Rolland, M., Arnaud, F., Chapron, E., Desmet, M., Givelet, N., Alibert, C., et al. (2005). Sr and Nd isotopes as tracers of clastic sources in Lake Le Bourget sediment (NW Alps, France) during the Little Ice Age: palaeohydrology implications. Chem. Geol. 224, 183-200. doi: 10.1016/j.chemgeo.2005. 04.014

Ríos, F., Kilian, R., Lange, C. B., Baeza-Urrea, O., Arz, H. W., Zindorf, M., et al. (2020). Environmental and coastline changes controlling Holocene carbon accumulation rates in fjords of the western Strait of Magellan region. Continental Shelf Res. 199:104101. doi: 10.1016/j.csr.2020.104101

Ross, L., Pérez-Santos, I., Valle-Levinson, A., and Schneider, W. (2014). Semidiurnal internal tides in a Patagonian fjord. Progr. Oceanogr. 129, 19-34. doi: 10.1016/j.pocean.2014.03.006

Sagredo, E. A., and Lowell, T. V. (2012). Climatology of Andean glaciers: a framework to understand glacier response to climate change. Glob. Planetary Change 8, 101-109. doi: 10.1016/j.gloplacha.2012.02.010

Sandgren, P., and Snowball, I. (2001). “Application of mineral magnetic techniques to paleolimnology," in Tracking Environmental Change Using Lake Sediments Volume 2: Physical and Geochemical Methods, eds W. M. Last and J. P. Smol (Dordrecht: Kluwer Academic Publishers), 217-237.

Scofield, N., and Roggenthen, W. M. (1986). Petrologic evolution of plagioclaserich cumulates from the Wichita Mountains, Oklahoma: effects upon magnetic remanence properties. Geology 14:908. doi: 10.1130/0091-7613198614<908: $\mathrm{PEOPCF}<2.0$.CO;2

Segemar (2003). Mapa Geológico de la Provincia de Santa Cruz, Republica Argentina. 1:750 000

Sernageomin (2003). Mapa Geológico de Chile: versión digital. Servicio Nacional de Geología y Minería, Publicación Geológica Digital No. 4, (CD-ROM, versión1.0, 2003). Santiago: Servicio Nacional de Geología y Minería.

Shin, J. Y., Kim, S., Zhao, X., Yoo, K. C., Yu, Y., Lee, J. I., et al. (2020). Particlesize dependent magnetic properties of Scotia Sea sediments since the Last Glacial Maximum: glacial ice-sheet discharge controlling magnetic proxies. Palaeogeogr. Palaeoclimatol. Palaeoecol. 557:109906. doi: 10.1016/j.palaeo.2020. 109906

Siani, G., Colin, C., Michel, E., Carel, M., Richter, T., Kissel, C., et al. (2010). Late Glacial to Holocene terrigenous sediment record in the Northern Patagonian margin: paleoclimate implications. Palaeogeogr. Palaeoclimatol. Palaeoecol. 297, 26-36. doi: 10.1016/j.palaeo.2010.07.011

Snowball, I., Sandgren, P., and Petterson, G. (1999). The mineral magnetic properties of an annually laminated Holocene lake-sediment sequence in northern Sweden. Holocene 9, 353-362. doi: 10.1191/095968399670520633

St-Onge, G., Chapron, E., Mulsow, S., Salas, M., Viel, M., Debret, M., et al. (2012). Comparison of earthquake-triggered turbidites from the Saguenay (Eastern Canada) and Reloncavi (Chilean margin) Fjords: implications for paleoseismicity and sedimentology. Sedimentary Geol. 243-244, 89-107. doi: 10.1016/j.sedgeo.2011.11.003

Stuut, J. W., Kasten, S., Lamy, F., and Hebbeln, D. (2007). Sources and modes of terrigenous sediment input to the Chilean continental slope. Quaternary Int. 161, 67-76. doi: 10.1016/j.quaint.2006.10.041

Syvitski, J. P., and Shaw, J. (1995). Sedimentology and Geomorphology of Fjords. Dev. Sedimentol. 53, 113-178. doi: 10.1016/S0070-4571(05)80025-1

Van Daele, M., Versteeg, W., Pino, M., Urrutia, R., and De Batist, M. (2013). Widespread deformation of basin-plain sediments in Aysén fjord (Chile) due to impact by earthquake-triggered, onshore-generated mass movements. Mar. Geol. 337, 67-79. doi: 10.1016/j.margeo.2013.01.006

Vandekerkhove, E., Bertrand, S., Mauquoy, D., McWethy, D., Reid, B., Stammen, S., et al. (2020). Neoglacial increase in high-magnitude glacial lake outburst flood frequency, upper Baker River, Chilean Patagonia (47 $\mathrm{S})$. Quaternary Sci. Rev. 248:106572. doi: 10.1016/j.quascirev.2020.106572

Villaseñor, T., Tentori, D., Marsaglia, K. M., and Pinto, L. (2019). The changing Patagonian landscape: erosion and westward sediment transfer paths in northern Patagonia during the Middle and Late Pleistocene. Basin Res. 32, 1035-1053. doi: 10.1111/bre.12413

Weltje, G. J. (2012). Quantitative models of sediment generation and provenance: state of the art and future developments. Sedimentary Geol. 280, 4-20. doi: 10.1016/j.sedgeo.2012.03.010

Weltje, G. J., and Tjallingii, R. (2008). Calibration of XRF core scanners for quantitative geochemical logging of sediment cores: theory and 
application. Earth Planetary Sci. Lett. 274, 423-438. doi: 10.1016/j.epsl.2008. 07.054

Wils, K., Van Daele, M., Kissel, C., Moernaut, J., Schmidt, S., Siani, G., et al. (2020). Seismo-turbidites in aysén fjord (Southern Chile) reveal a complex pattern of rupture modes along the 1960 megathrust earthquake segment. J. Geophys. Res.: Solid Earth 125, 1-23. doi: 10.1029/2020JB019405

Wils, K., Van Daele, M., Lastras, G., Kissel, C., Lamy, F., and Siani, G. (2018). Holocene event record of aysén fjord (Chilean Patagonia): an interplay of volcanic eruptions and crustal and megathrust earthquakes. J. Geophys. Res.: Solid Earth 123, 324-343. doi: 10.1002/2017JB0 14573
Conflict of Interest: The authors declare that the research was conducted in the absence of any commercial or financial relationships that could be construed as a potential conflict of interest.

Copyright $\odot 2021$ Troch, Bertrand, Amann, Liu, Placencia and Lange. This is an open-access article distributed under the terms of the Creative Commons Attribution License (CC BY). The use, distribution or reproduction in other forums is permitted, provided the original author(s) and the copyright owner(s) are credited and that the original publication in this journal is cited, in accordance with accepted academic practice. No use, distribution or reproduction is permitted which does not comply with these terms. 